\title{
Climatic Changes and Their Impacts in the Mediterranean during the First Millennium AD
}

\author{
Inga Labuhn, Martin Finné, Adam Izdebski, Neil Roberts and Jessie Woodbridge
}

\begin{abstract}
Many events and developments in human history have been suspected to be, at least partly, influenced by climate and environmental changes. In order to investigate climate impacts on societies, reliable palaeoclimatic data of adequate dating precision, resolution, spatial representativeness, and so on, are needed. This paper presents a survey and analysis of published palaeoclimatic data of the Mediterranean for the 1st millennium $\mathrm{AD}$, and identifies regional patterns of hydroclimate variability, useful for comparison with archaeological/historical studies. It also provides general guidelines to palaeoclimatic data for archaeologists/historians interested in climatic change. We conclude with a discussion of how the emerging patterns of regional climate histories may have had an impact on Mediterranean societies in Late Antiquity.
\end{abstract}

\section{Introduction}

Compared to other regions of the world, the Mediterranean is characterised by a wealth of archaeological studies and historic documents, as well as a relatively dense network of palaeoclimatic data that makes it a perfect case study to investigate the potential influence of climate on civilisations. The dramatic political, economic, cultural and ecological transformations of the end of antiquity and the beginning of the Middle Ages ( $c a$. AD 300-800) occurred in particular climatic contexts, and a number of recent studies have suggested that climatic change played a role in at least some of them. ${ }^{1}$

Linking archaeological evidence or historic documents with palaeoclimatic reconstructions is challenging, not only because of the often complex causal relationships, but also because all these types of evidence only provide an incomplete picture of the past, and are all afflicted with uncertainties. Archaeological studies document societal changes related to settlements, migration, or agricultural practices, for example, however, the causes of such changes are more difficult to deduce from the archaeological material. On the other hand, historical documents may be more specific in this respect, but can be incomplete, discontinuous or biased by the point of view of the observer. Palaeoclimatic data might sometimes be considered to be 'hard' scientific facts. However, climate reconstructions are interpretations, or statistical based estimates, of the climate state for the pre-instrumental period, and there is uncertainty related to sampling, laboratory analyses, chronology, replication and calibration, which should be clearly communicated by the investigator. These uncertainties are inherent to the material that archaeologists, historians and scientists work with, but some may be overcome as new investigations add pieces to the puzzle. That is why the study of climate and history requires an interdisciplinary approach. This paper investigates the ways in which climatic variability may have had an impact on the course of human history in Late Antiquity and beyond, by providing a detailed overview of the existing palaeoclimatic data from the Mediterranean region for the ist millennium AD.

\section{Previous Reviews of Mediterranean Palaeoclimate}

A number of previously published studies have dealt with climate changes during past millennia in the Mediterranean and/or have reviewed the existing data. McCormick and others have presented published data on climate conditions in Roman and post Roman times (ca. $100 \mathrm{BC}$ to $\mathrm{AD} 800$ ), combining historical and archaeological evidence with a number of palaeoclimatic records, including reconstructions of climate forcings (solar radiation, volcanic eruptions). ${ }^{2}$ The authors inferred generally warm and stable climate conditions during the 'Roman optimum' (ca. $100 \mathrm{BC}$ to AD 200), followed by cooler, more unstable and spatially heterogeneous climatic conditions in the following centuries. Luterbacher and others have provided a more exhaustive review of existing palaeoclimatic evidence for the Mediterranean during the last 2,00o years, focusing on high resolution terrestrial and marine data. ${ }^{3}$ These authors presented data overviews organised by climate ar-

2 McCormick et al. (2012).

3 Luterbacher et al. (2012).

1 E.g. Newfield (2018); Büntgen et al. (2016); Izdebski et al. (2016), to give just the most recent examples. 
chive, and discussed the opportunities, challenges and limitations for local to large-scale climate reconstructions across the Mediterranean.

Finné and others presented a detailed multi-proxy compilation of palaeoclimatic data and reconstructions of the last 6000 years for the eastern Mediterranean, by analysing temporal and spatial patterns of precipitation and temperature. ${ }^{4}$ They found large differences in quantitative temperature reconstructions, both with respect to absolute values and relative changes. Due to uncertainties in dating and calibration, it is difficult to determine whether these differences are linked to actual differences in local climates. The authors also acknowledged the difficulty in interpreting and comparing records with respect to short-term climate variability of low amplitude, which is relevant in the temporal context of Late Antiquity. More recently, Izdebski and others investigated climate changes and their societal impacts in the eastern Mediterranean (Anatolia and Levant) during Late Antiquity, based on environmental, archaeological, and historical evidence. ${ }^{5}$ They identified a Late Roman drought in the 4th and 5 th c. AD, followed by a dramatic shift to much wetter climatic conditions, with increasing dryness again from $c a$. 700. While these changes appear to have impacted such processes as the expansion or decline of rural settlements on marginal lands, the authors highlight that the lack of chronological precision in the dating of the archaeological evidence and climate proxy records, hampers conclusions on the societal responses to climate change.

\section{Aims of this Paper}

Our review aims to facilitate the integration of the 'climate factor' into accounts of Late Antiquity by focusing on the regionality of climatic change in the Mediterranean at the turn between the ancient and medieval periods. Building upon the above mentioned studies, this paper provides an updated survey and analysis of palaeoclimatic data for the entire Mediterranean region during the 1st millennium $\mathrm{AD}$. As we demonstrate below, the Roman and post Roman Mediterranean was characterised by a high degree of spatial variability when it comes to climatic trends. While there was no uniform 'Roman' or 'pan-Mediterranean' climate, we show that different parts of the Mediterranean coalesced into larger climatic regions, and major transitions in regional climatic patterns were often synchronous, even if taking different directions.

We first give a short introduction to palaeoclimatology for historians and archaeologists, raising issues

\footnotetext{
4 Finné et al. (2011).

5 Izdebski et al. (2016).
}

related to dating precision, resolution, proxy sensitivity and so on. This may help them evaluate the scientific results and the usefulness of proxy records and climate reconstructions for a specific purpose. Secondly, we provide a compilation of the available well-dated, high resolution palaeoclimatic records (which are less abundant for this period than for later centuries) that are relevant for interdisciplinary studies of the Mediterranean region's environmental history. Thirdly, we identify clusters or climatic regions around the Mediterranean based on these data compilations using numerical methods, and assess the regional coherence in different reconstructions, being aware of the limitations due to dating precision and resolution. Lastly, we discuss how the emerging patterns of regional climate histories in the Mediterranean of the 1st millennium AD could be related to socio-economic and political processes.

\section{Palaeoclimatology and Climate Proxy Data in the Context of Late Antiquity}

The Earth's climate is constantly changing. The principal control on climate variability is the Earth's radiation balance, which is influenced by various external and internal forcings. The Earth receives its energy in the form of shortwave radiation from the Sun. The incoming solar radiation changes with the cyclic variations of the Earth's orbit and its axial tilt, and with variations in solar activity. ${ }^{6}$ The orbital parameters lead to variations on diurnal and seasonal time scales with the rotation of the Earth and its orbit around the Sun, as well as on time scales of tens of thousands of years through changes in eccentricity, obliquity and precession. A part of the incoming solar radiation is absorbed, and the rest is reflected back into space by the atmosphere or the Earth's surface, which is known as the planetary albedo. ${ }^{7}$ Finally, the longwave radiation emitted from the Earth is absorbed and re-emitted by atmospheric gases, which raises the global surface temperature. This is referred to as the 'greenhouse effect'. 8 The input of aerosols from large volcanic eruptions into the atmosphere is an important driver of climate variability on inter-annual to decadal time scales. ${ }^{9}$ Further, the global climate system is governed by complex processes, interactions and feedback mechanisms between the atmosphere, hydrosphere, cryosphere, biosphere, and land

6 Earth's orbit and axial tilt: Berger and Loutre (1991); Hays et al. (1976). Solar activity: Bard et al. (2000).

7 Donohoe and Battisti (2011).

8 Mitchell (1989).

9 Sigl et al. (2015). 
surfaces, which act on different spatial and temporal scales.

Palaeoclimatology is the study of climate prior to the widespread availability of instrumental meteorological data. ${ }^{10}$ Natural climate archives, such as ice cores, tree rings, corals, lake and marine sediments and speleothems, can provide information about pre-instrumental variations in temperature, precipitation, drought and other variables, as well as providing data about forcing mechanisms, such as solar variability and volcanism. By definition, the formation processes of a natural archive are influenced by climatic and environmental parameters. The archive must be datable, so that a chronology of the reconstructed climatic/environmental change can be established. A proxy is an indirect indicator of climate that is recorded in a natural archive, for example the width of tree rings.

Whether a proxy record is adequate for comparison with historical events and developments depends on its geographic location, temporal range, dating precision, as well as the resolution of the proxy measurements, the sensitivity of the proxy, the kind of climate and environmental information that can be derived from it, and whether it allows a quantification of climate variability. The following issues should be considered when working with proxy-based palaeoclimate reconstructions in a historical/archaeological context.

\section{Dating Methods/Chronology}

The identification of climate impacts on societies remains speculative without a precise chronology of the climate proxy data. Dendrochronology is the most exact of all dating methods, because a precise year can be identified for each tree ring, and verified, both visually and statistically, by comparing ring width patterns between trees (known as cross-dating). ${ }^{11}$ Other archives can also form annual layers under certain conditions, such as corals, lake sediments and speleothems. ${ }^{12}$ However, layer counting errors increase counting back in time because a cross-validation, such as the approach used for tree rings, is usually not possible. In sediments we can identify marker layers, for example volcanic tephra layers that can be linked to a volcanic eruption of a known date, ${ }^{13}$ or peaks in atmospheric lead pollution related to known peaks in lead emissions. ${ }^{14}$ Such markers provide important tie points, but no continuous

10 For introductory textbooks on palaeoclimatology, see e.g. Bradley (2015); Lowe and Walker (2015).

11 Cook and Kairiukstis (1990).

12 Baker et al. (2008); Zolitschka et al. (2015).

13 Lowe (2011).

14 Renberg et al. (2001). chronology. Radiometric dating methods estimate the age of a sample through measurements of radioactive isotopes and their decay products. Radiocarbon and Uranium-Thorium dating are the most commonly used radiometric dating methods for samples of past centuries to millennia. ${ }^{15}$ Again, no continuous chronology is obtained, but an interpolation between dated points using an age-depth model ${ }^{16}$ is required to assign a date to each proxy measurement.

Uncertainties for ages retrieved through radiocarbon dating relate to analytical errors associated with the measurement, and the uncertainties involved in the calibration to calendar years using a calibration curve. Additionally, the uncertainties of radiocarbon dating can further increase by reservoir effects, such as the so-called 'hard water effect' and the 'marine reservoir effect'. The hard water effect occurs in areas with limestone bedrock (such as the Mediterranean basin) when old, inert carbon from the carbonate rock dissolves in the water, and is subsequently incorporated into living organisms and sediments. ${ }^{17}$

Dating uncertainties have an impact on our ability to know when something occurred, but they also have an effect on the temporal resolution. However, the temporal resolution can theoretically be separated from radiometric dating uncertainties if proxy data are derived from annually laminated archives. Both timing, duration and pace of change are key factors when relating palaeoenvironmental data to human perspectives derived from archaeological/historical datasets.

\section{Temporal Resolution}

If societal developments or events that are suspected to be influenced by climate change take place within a few years or decades, highly resolved climate proxies are needed, which reflect climate changes on a fine temporal scale and allow us to precisely identify rates of changes. The resolution that can be obtained from a climate archive can vary from seasonal to millennial, and depends on its growth/deposition rate, as well as on sampling techniques and the amount of material that is needed to perform proxy measurements.

\section{Spatial Representativeness}

Local proxy records can be representative of a larger region if their dominant influence is linked to largerscale climate and atmospheric circulation. Generally, we can expect temperature changes to be relatively

\footnotetext{
15 Hua (2009); Richards and Dorale (2003).

16 Scholz et al. (2012).

17 Walker (2005).
} 
homogeneous for a region like the Mediterranean, ${ }^{18}$ whereas precipitation patterns show a much largerspatial variability. ${ }^{19}$ Precipitation variability occurs on regional as well as local levels, and differences are even seen at the micro level, such as between adjacent valleys. How far climate reconstructions from distant sites can be considered representative for a given region may be tested using instrumental measurements and pseudo proxy experiments with climate models. ${ }^{20}$ However, it must be kept in mind that even if spatial coherence exists for recent periods, this may not have been the case in the past.

\section{Proxy 'Calibration'}

The meaning of a given proxy is not always the same, and depends on its local context: climate, geology, hydrology and so on. For example, tree growth in high altitude environments with short growing seasons strongly depends on temperature, and tree ring width can be interpreted as a temperature proxy. In warm, arid environments, tree growth is more dependent on available water than on temperature, and the same proxy can be interpreted as a precipitation, drought or soil moisture proxy. The interpretation of proxy data in terms of meteorological variables requires a detailed understanding of how climate influences the physical, chemical and biological processes that lead to the formation of the climate archive. If possible, the statistical relationship between the proxy and the climate variable(s) that control it, must be determined. Linking a proxy with climate in order to infer climate information is known as calibration. Some proxy measurements can be directly compared with instrumental meteorological data, but this is restricted to high resolution proxy data with a high dating precision, and to regions with long instrumental meteorological records. This is common practice in tree ring studies, ${ }^{21}$ but can be possible for other archives.

Highly resolved speleothem records, combined with a monitoring of local meteorological and hydrological conditions over several years, may also allow calibration of a proxy, such as oxygen isotope ratios versus precipitation amounts. ${ }^{22}$ The climate-proxy relationship established for present-day conditions is then extrapolated beyond the period of instrumental measurements, assuming it has remained constant over time, although this is not always the case. Such direct comparisons also allow a quantification of the climate reconstruction, that is, proxy measurements can be interpreted as ab-

\footnotetext{
18 E.g. Luterbacher et al. (2016).

19 E.g. Xoplaki et al. (2004).

20 E.g. Smerdon (2012) and references therein.

21 Fritts and Guiot (1990).

22 E.g. Bar-Matthews and Ayalon (2004); Jex et al. (2010).
}

solute temperature or precipitation amounts, which is important in understanding the magnitude of changes. Importantly, such reconstructions should include a measure of uncertainty that expresses how likely it is that reconstructed values fall in a certain range. In many cases however, reconstructions are qualitative, indicating 'warm'/'cold' or 'wet'/'dry' conditions.

\section{Proxy Sensitivity}

Proxy sensitivity denotes to what extent a proxy is climate dependent. In the context of Late Antiquity, on a time scale of a few centuries, there are no major shifts in the Earth's climate system, such as transitions from glacial to interglacial periods. Nevertheless, changes have occurred, and even subtle changes might have had significant influence on societies if certain thresholds were crossed. For example, a slight decrease in precipitation can have severe consequences for an established agricultural system if the water demand of the crops is no longer met. Climate reconstructions on this temporal scale need sensitive proxies that respond to such changes, and allow the climate signal to be distinguished from the 'noise' inherent in each proxy record: that is, the random variability in the proxy record which is not linked to climate change.

In the Mediterranean, humans have had a significant impact on their environment and have modified landscapes. This has a potential influence on several climate proxies and could mask the climate signal contained in the proxies. This is especially important for pollen records, that reflect land use changes as well as climateinduced vegetation changes. It is also a factor, albeit to a lesser extent, for some other archives, such as lake sediments, which are impacted by anthropogenic activities in the catchment, or speleothems, which respond to anthropogenic vegetation changes above a cave.

\section{Seasonality}

Proxy records can be controlled by average annual climate, or climate related to a specific season. ${ }^{23}$ However, it is not always straightforward to attribute a season to a proxy. Tree rings for example reflect the climatic conditions during the growing season, but in regions where most precipitation falls in the winter, this season will also have an impact on tree growth, because this is when the soil water reservoir is replenished. Comparisons of proxy records can be hampered if the proxies are biased towards different seasons. ${ }^{24}$ The season which is represented by a proxy can also change over time, such as if

\footnotetext{
23 Catalan et al. (2002).

24 E.g. Gildor and Ghil (2002).
} 
a proxy is influenced by precipitation and the precipitation seasonality changes.

\section{Present-Day Mediterranean Climate}

The Mediterranean basin is the largest area of the world to experience a climate of summer drought, winter rain of cyclonic origin and a mean annual temperature of $15 \pm 5^{\circ} \mathrm{C}$ (Köppen type Cs). It marks a transitional zone between the North African-Arabian arid zone, dominated by subtropical high pressure, and central-northern Europe, affected by westerly circulation. Precipitation is largely cyclonic of Atlantic origin, although local cyclogenesis occurs in the sea south of Genoa and near Cyprus.

Inter-annual variability in precipitation is therefore influenced by the synoptic conditions that also affect other parts of western Europe. Observational records of precipitation in the western Mediterranean show a strong positive correlation with the state of the North Atlantic Oscillation (NAO) index..$^{25}$ Instrumental precipitation records for the north-eastern sector of the Mediterranean show a weaker negative correlation with the NAO, a link that may also be evident in riverdischarge and tree ring records. ${ }^{26}$ This part of the Mediterranean can also be strongly influenced by the western Russian and/or Scandinavian High Pressure System in winter. ${ }^{27}$ The influence of the Saharo-Arabian arid zone to the south is felt primarily during summer, when anticyclonic conditions migrate north to create seasonal drought. Summer monsoonal rains rarely reach as far north as the Mediterranean Sea, so that precipitation sources in the Maghreb and the Sahel are decoupled, and rainfall time-series show no correlation. ${ }^{28}$ However, there are teleconnections between the South Asian monsoon and summer weather conditions in the eastern Mediterranean, for example, via the 'meltem' or Etesian winds. ${ }^{29}$

\section{Data Compilation and Analysis}

The usefulness of a specific palaeoclimate proxy dataset or reconstruction in an archaeological context, depends on the research question and the temporal and spatial scales considered. Ideally, we would need 'high'

\footnotetext{
25 Trigo et al. (2004); Xoplaki et al. (2004).

26 Cullen and de Menocal (2000).

27 E.g. Corte-Real et al. (1995); Lionello et al. (2006).

28 Ward et al. (1999).

29 Ziv et al. (2004).
}

resolution records with a 'precise' chronology, from a geographic location of the proxy record whose climate is representative of the archaeological site or region of interest. However, the number of available high-resolution records, notably from tree rings, greatly decreases before $c a . \mathrm{AD} 1000$, in the Mediterranean region as well as globally. ${ }^{30}$ Due to the limitations of the available data, we do not apply any hard selection criteria, but consider datasets of decadal to centennial resolution, with a dating precision of \pm 100 years or better. Furthermore, records should cover at least a large part of the 1st millennium AD.

Our data compilations are based on previous work (see 'Introduction' above) and is complemented by more recent studies published up to 2016. Principal sources were the Pangaea and NOAA palaeoclimatic databases, ${ }^{31}$ as well as data provided by authors of the original studies. We consider principally local records from sites around the Mediterranean, as well as larger-scale reconstructions based on multiple records. Records that are less clearly linked to climate variability, or have significant non-climatic influences (such as sea level changes, pollen or charcoal records) will not be considered here. ${ }^{32}$ Pollen records for the Mediterranean cannot be used in a straightforward way as primary evidence for climate change during the ist millennium AD due to the difficulty of separating human impact from climatic and other factors. While vegetation changes reflected in fossil pollen assemblages may reflect climate-induced vegetation change, they are often interpreted as proxies for land use change in the Mediterranean context, where human influence on the landscape has been significant. Land use change can be influenced by climate change (for example in the choice of more drought-resistant crops), and thus provide supporting evidence for reconstructed climate variability, but are also very susceptible to other changes, such as markets, war, agricultural techniques, and so on. ${ }^{33}$ An overview of the palaeoclimatic data compiled in this study is given in Table 1.

30 Luterbacher et al. (2012); Masson-Delmotte et al. (2013); Christiansen and Ljungqvist (2017).

31 Accessible at www.pangaea.de and www.ncdc.noaa.gov/ data-access/paleoclimatology-data/datasets.

32 But see the review by Luterbacher et al. (2012) which includes these. Regional vegetation histories are presented in other papers in this volume.

33 Nile floods, although an environmental parameter with a significant impact on society, will not be considered here either. The Nile flood is determined by summer rainfall over Ethiopia, which in turn links to the Indian monsoon, not to winter cyclonic precipitation of Atlantic origin: Lionello et al. (2006). In our attempt to cluster palaeoclimate records, we 


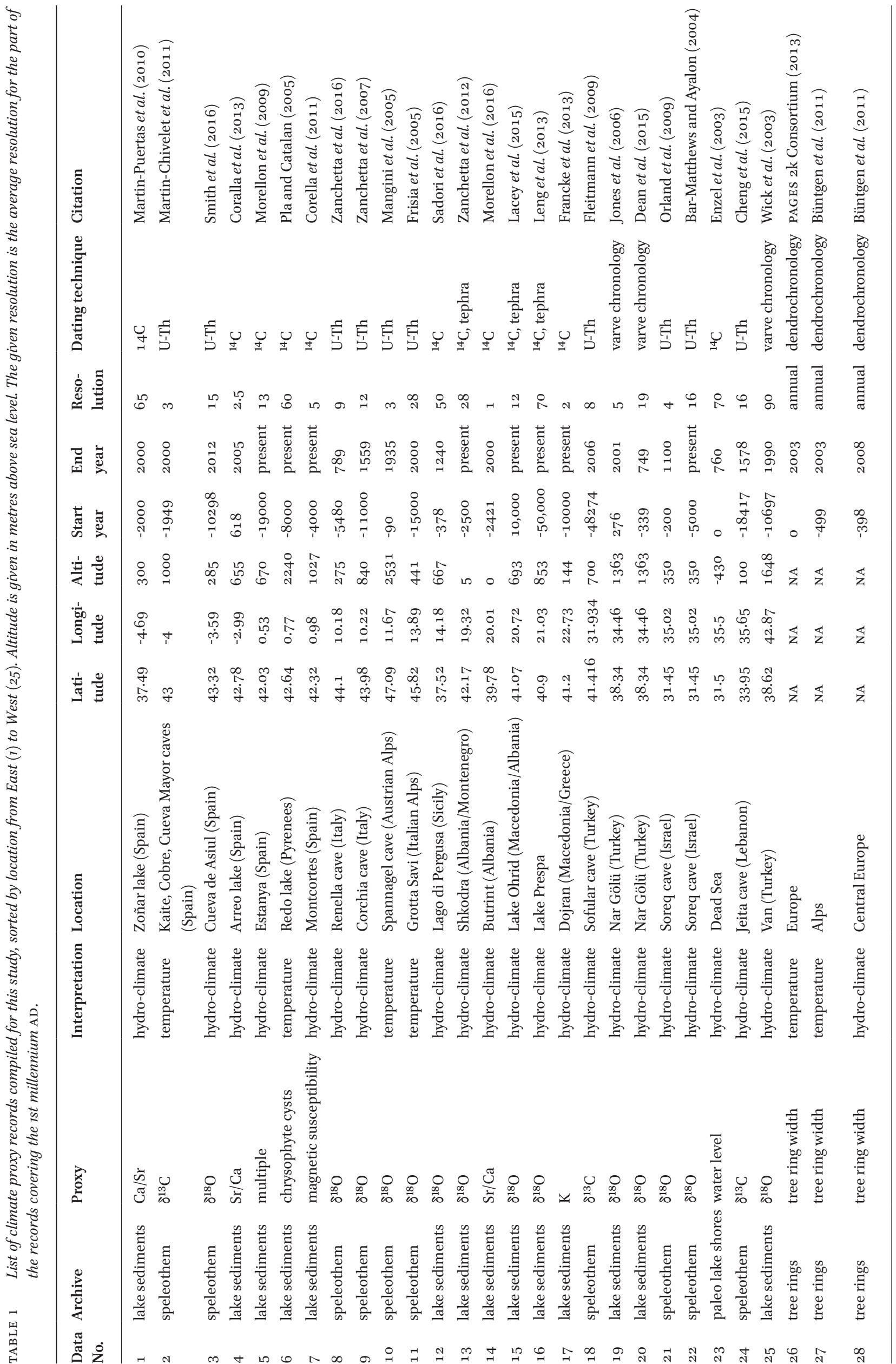


First, temperature proxies and reconstructions are discussed, followed by a comparison of the proxies for different variables related to hydro-climate, such as precipitation amount, drought, or runoff. As hydro-climate proxy records are more numerous than temperature records, they allow a quantitative analysis. Standardised zscores were calculated based on the mean and standard deviation for the part of the records spanning the period $\mathrm{AD}$ 0-1000. ${ }^{34} \mathrm{Z}$-scores create a 'common currency' that enables a direct comparison between individual records regardless of which climate proxy is involved. As the records have different resolutions and time steps, a regular, annually resolved time series was calculated for each record based on linear interpolation between data points. The new annual records were then split into 100year time slices, and average z-scores for each century were calculated. ${ }^{35}$ This permits numerical comparison between records, both via paired correlations between sites and via multi-site statistical ordination techniques. For the latter, we employed Principal Components Analysis (PCA $)^{36}$ to identify major axes of climate variations during the 1st millennium AD. PCA provides a means of identifying trends and patterns in complex datasets such as climate time series.

\section{Palaeoclimate Records of the Mediterranean}

The Mediterranean region cannot be considered a homogeneous entity in terms of its climate. Influences of orography, dominant wind directions and moisture sources, the distance from the coast, and so on, lead to a complexity of local climates. The large-scale significance of local climate reconstructions must be critically evaluated. ${ }^{37}$

\section{European Temperature Reconstructions}

As noted above, temperature changes are more homogeneous in space than precipitation changes. Even if absolute temperatures differ from place to place, the available local temperature reconstructions may to some degree be representative of the relative changes taking place around the Mediterranean. The longest high-resolution

therefore do not expect a link between Nile floods and the regional Mediterranean climate.

The period was restricted to avoid the influence of large shifts in longer records which extend, for example, to the Pleistocene-Holocene transition. We did not perform our analysis on the annually resolved time series, because this would suggest a level of detail that is not actually present in the proxy records. Performed using C2 software: Juggins (2014).

Luterbacher et al. (2012). temperature records in Europe come from Alpine and Scandinavian tree rings. Tree growth at these high elevation and high latitude sites is sensitive to changes in temperature, and here human influence has been less pronounced, so old trees are preserved. The advantage of these reconstructions is the precise dating (dendrochronology) and annual resolution, but like most tree ring based reconstructions, they are representative of the growing season temperature (spring-summer). The PAGES 2k Consortium summer temperature reconstruction summarised the European proxy data for the past two millennia (fig. 1). ${ }^{38}$ They show above average summer temperatures during the ist $\mathrm{c}$. $\mathrm{AD}$, followed by a decreasing trend, that culminates in a multi-decadal cold period following ca. 540, whose onset has been linked to the 536 atmospheric event, probably caused by major volcanic eruptions. ${ }^{39}$ The warm conditions of the early Roman empire and the multi-decadal 6th c. cooling - recently labelled the 'Late Antique Little Ice Age', thought to have lasted from 536 to around 66oare also visible in an Altai tree ring-based temperature reconstruction, ${ }^{40}$ suggesting that both were more global phenomenon, and so probably present across most of the Mediterranean. The centuries that followed $c a .660$ are characterised by increasing temperatures, with the exception of another multi-decadal cold period around 8oo. There is no equivalent dendro-climatological data from around the Mediterranean itself prior to $c a$. AD 1000, but we can compare the continental-scale temperature reconstruction with lower resolution local records.

\section{Local Temperature Reconstructions}

Few high-resolution temperature reconstructions, compared to hydro-climate ones, are available for the Mediterranean region, making it difficult to identify regional patterns of temperature changes during the 1st millennium AD. Temperature proxy records from the Alps give some indications as to the temperature just north of the Mediterranean region during the ist millennium AD (fig. 1). A speleothem $\delta^{18} \mathrm{O}$ record from Grotta Savi (sE Alps) ${ }^{41}$ indicates a temperature drop ca. 500-700, then an increase again until 1000, which agrees with the European tree ring data. Another Alpine speleothem temperature reconstruction from Spannagel Cave (Austria) ${ }^{42}$ also shows some similarities with the tree ring based reconstructions mentioned above, such as a temperature decrease after 500. Long-term trends,

\footnotetext{
$38 \quad$ PAGES 2k Consortium (2013).

39 Larsen et al. (2008); Sigl et al. (2015).

40 Büntgen et al. (2016).

41 Frisia et al. (2005).

42 Mangini et al. (2005).
} 


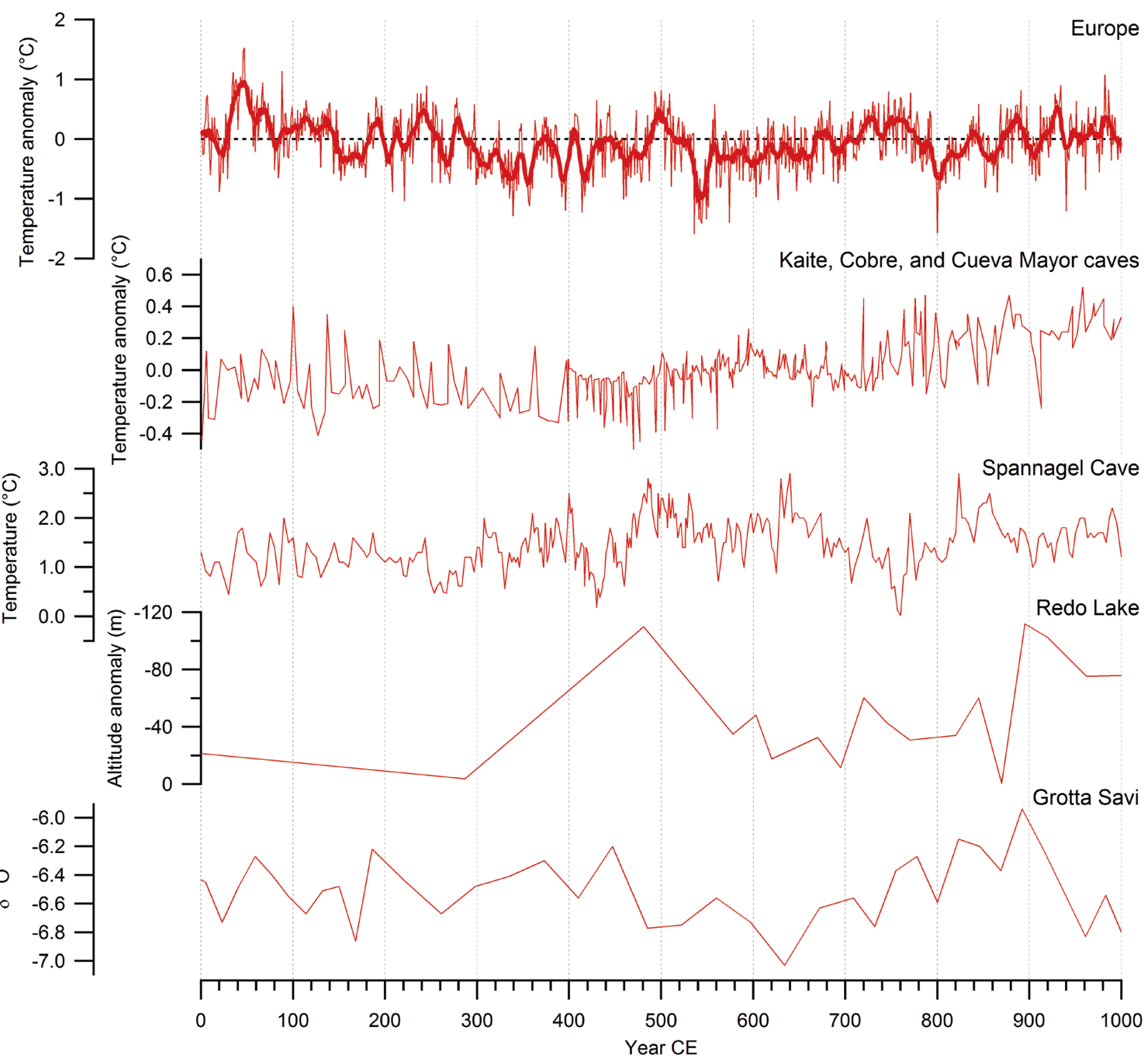

FIGURE 1 Top panel: European summer temperature reconstruction (PAGES $2 k$ Consortium (2013)), expressed as anomalies relative to the 1961-9o reference period $\left(\right.$ in $\left.{ }^{\circ} \mathrm{C}\right)$. The thick line is a ten-year moving average. Lower panels: local temperature reconstructions and temperature proxies. Proxies are plotted so that upward values represent warm temperatures and vice versa. See Table ifor references and locations.

however, are quite different. Overall, the second half of the ist millennium $\mathrm{AD}$ appears warmer than the first half, according to this reconstruction.

A similar trend can be observed in the temperature reconstruction from Spanish speleothems. ${ }^{43}$ In this record the 6th c. is characterised by a warming trend. Further information about the temperatures on the Iberian Peninsula come from Lake Redó, located at high elevation in the Spanish Pyrenees. ${ }^{44}$ At this site, a chrysophyte transfer function applied to this $70 \mathrm{~m}$ deep glacial lake provided a temperature reconstruction which shows warm winters occurred around AD 450, and at the start of the Medieval Climate Anomaly ca. 900 (fig. 1).

Two records from Anatolia give insights as to temperature variability during the 1 st millennium $\mathrm{AD}$ in the eastern Mediterranean. A speleothem $\delta^{13} \mathrm{C}$ record from Kocain Cave in SW Turkey ${ }^{45}$ has been tentatively interpreted as a proxy for winter temperature and snow cover. This reconstruction suggests cold temperatures (and increased snow cover) during the first two centuries $\mathrm{AD}$, followed by mostly warmer temperatures until $c a$. 650, with the 6th c. as an exception. After $c a .650$,

45 Göktürk (2011). 
there is an overall trend towards colder conditions, and at the end of the ist millennium AD conditions are colder and snowier again. The differences between $\delta^{18} \mathrm{O}$ composition of biogenic silica and carbonates from lake sediments of Nar Gölü, in central Turkey, has been used as a proxy for winter snowfall, as these hosts are formed in early spring and early summer, respectively. ${ }^{46}$ They inferred more significant snow cover, and therefore possibly colder winters, in the period AD 301-801, and again (although less markedly) from 921 to 1071. The former period does not seem to be reflected in Kocain Cave, whereas the latter one seems to be in agreement.

In summary, most of the available local temperature proxies suggest that some parts of the period up to ca. 250 were relatively warm, and they also record a cool interval of varying duration centred on the 6th c. However, there is no Mediterranean-wide agreement on overall temperature trends for the 1st millennium $\mathrm{AD}$, with some records showing temperatures to be consistently above the long-term average, while others suggest that either the earlier or the later part of the millennium was warmer.

\section{Hydro-Climate Reconstructions}

Continental-scale reconstructions, such as for temperature, do not exist for hydro-climate, because its spatial variability does not allow such generalisations. ${ }^{47}$ Reconstructions on a finer spatial scale than 'the Mediterranean region' are necessary to investigate possible influences of hydro-climatic changes on societies. A number of studies have compared hydro-climate records on different time scales, and found contrasting patterns both Mediterranean-wide and within sub-regions.

An east-west 'climate see-saw' has been identified in the hydro-climatic conditions of the Mediterranean, with dry conditions in Iberia and wet conditions in Anatolia during the Medieval Climate Anomaly, and inverse conditions in these two regions during the Little Ice Age. ${ }^{48}$ This analysis was limited to the period after AD 90o, however. A seesaw pattern was also observed for the period $3000-1000$ yr. B.P., where it was demonstrated that climate during this period was typified by a millennial-scale see-saw in climatic humidity between Spain and Israel on one side, and the central Mediterranean and Turkey on the other. ${ }^{49}$

Even on finer spatial scales, several studies of Mediterranean palaeoclimate proxies have found significant

\footnotetext{
46 Dean et al. (2013).

47 Seager et al. (2007).

48 Roberts et al. (2012).

49 Dermody et al. (2012).
}

differences in local hydro-climate. A comparison of reconstructions from Anatolia and the Levant suggests some differences in the amplitude and timing of wet and dry phases during Late Antiquity. ${ }^{50}$ While these spatial differences are not impossible climatologically, ${ }^{51}$ it may be that these climate phases were broadly synchronous between Anatolia and the Levant, and the apparent time offsets are mostly due to the uncertainties of the palaeoclimatic data. That is, they are lower-resolved and involve more chronological uncertainties for the Levant than for Anatolia.

It is difficult to test this rigorously due to these uncertainties, and also because of the potential differences in the sensitivity of a specific proxy. However, a persistent out-of-phase climate variability has been found between the north and south of the Levant, on a wide range of timescales, when comparing speleothem $\delta^{18} \mathrm{O}$ records from two different caves. ${ }^{52}$ Furthermore, there are indications that spatial relationships are not constant over time, as rainfall amounts on the Turkish Black Sea coast sometimes appear to be linked to the eastern Mediterranean climate, and sometimes not..$^{53}$

The 'Old World Drought Atlas' (OWDA) ${ }^{54}$ is a tree ring-based, annually resolved field reconstruction of the Palmer Drought Severity Index (PDSI) (AD 0-2000) that includes part of the Mediterranean region. However, the presented drought maps suggest a spatial resolution that is not given by the proxy records, especially for the 1st millennium AD. We will therefore not consider this reconstruction in our analysis, because drought occurrence and magnitude, during our period of interest, are extrapolated from distant locations (central/northern Europe), as no tree ring records from the Mediterranean region itself are available. ${ }^{55}$

\section{Regional Patterns of Hydro-Climate Variability}

The identification of regional climate patterns based on available proxy evidence remains challenging because of the uncertainties in chronologies, low resolution of records, and subtle changes that must be identified on timescales of a few centuries. This is further complicated by regional discrepancies in the density of available proxy data. Although there are relatively few high resolution palaeoclimate records from the Mediterranean region overall, the eastern Mediterranean is comparatively rich in palaeoclimatic data for the ist millennium $\mathrm{AD}$,

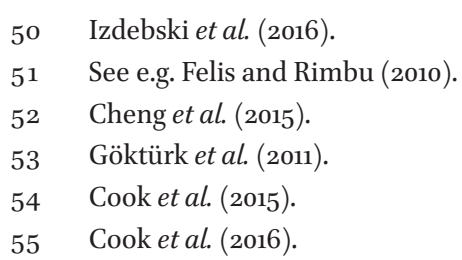




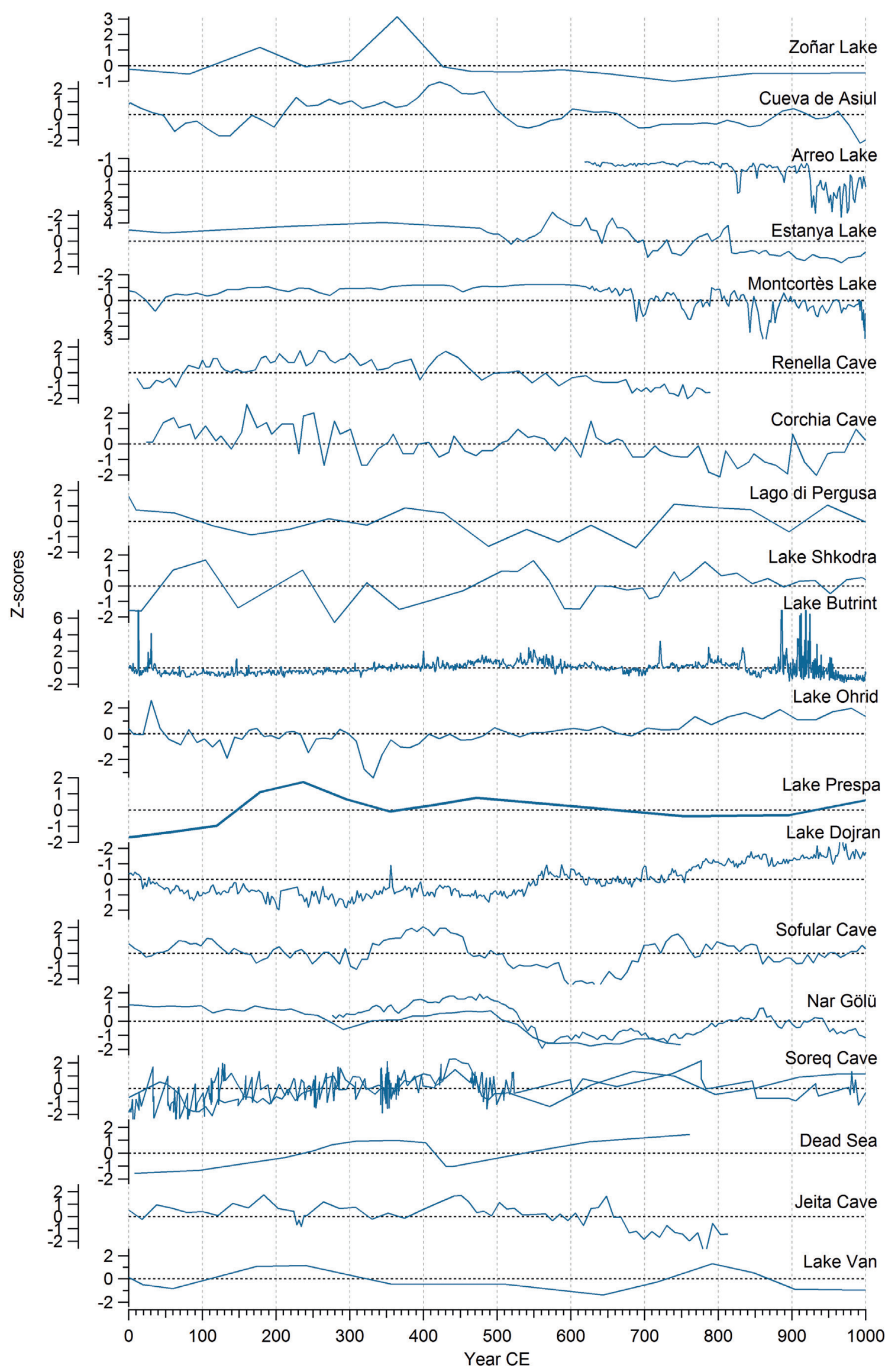

FIGURE 2 Hydro-climate proxies, transformed to z-scores and arranged from East (top) to West (bottom). All records are plotted so that upward values represent dry conditions and vice versa. Note that the interpretation of the presented proxies in terms of hydro-climate conditions is not always straightforward, and none of them can be regarded as representing only precipitation amount or humidity. The reader is advised to refer to the original publications for detailed discussions of the uncertainties in the respective chronologies and proxy interpretations. See Table 1 for references and locations. 

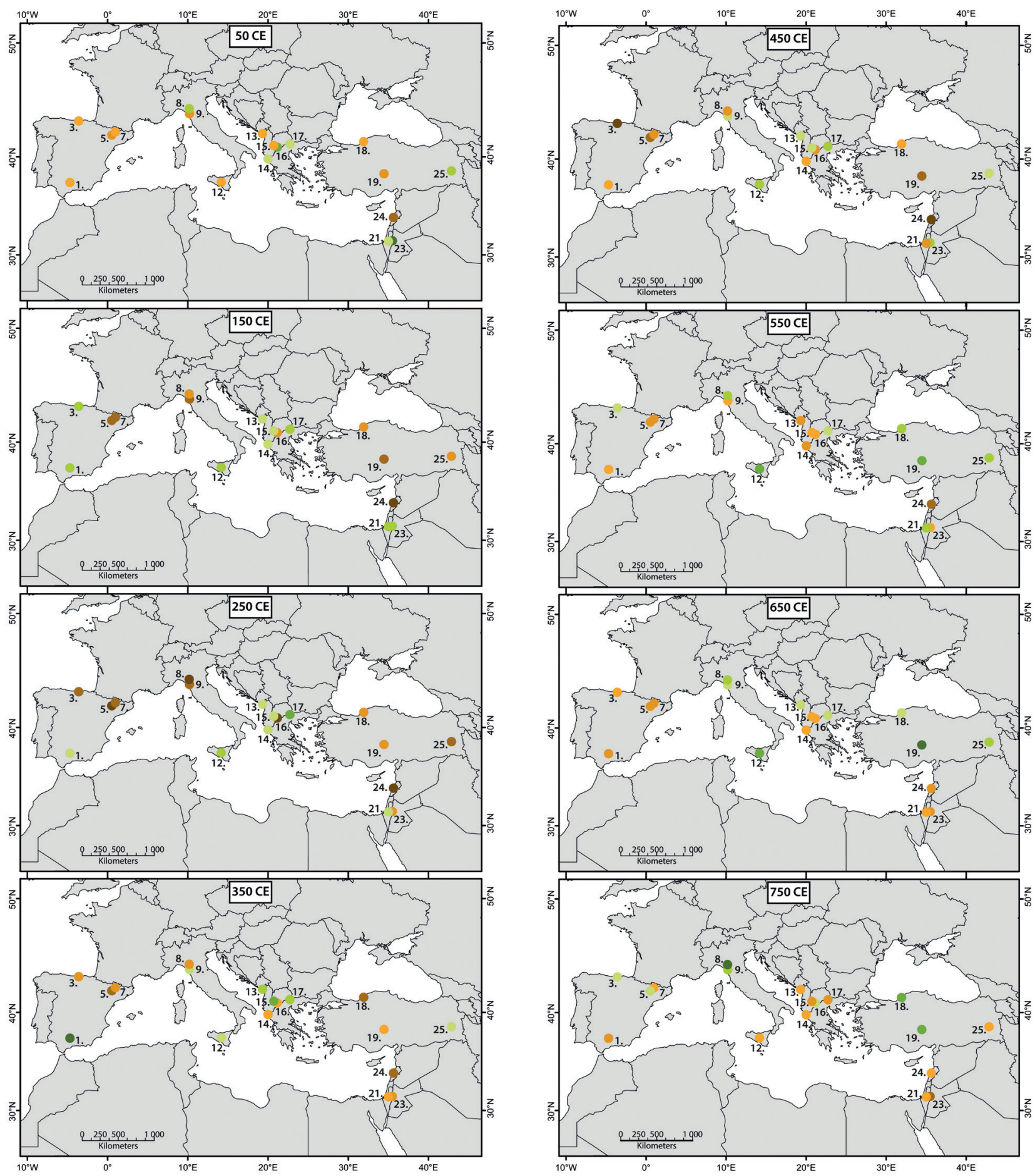

FIGURE 3 Average z-scores of each hydro-climate proxy record for each century. Negative values (green) reflect wetter than average conditions, positive value (brown) show drier conditions. Site numbers correspond to the numbers given in Table 1.

and so is the Iberian peninsula. Records are also available from the central Mediterranean (Italy and the Balkans), allowing the investigation of larger-scale regional differences. However, it is important to bear in mind that there are no high-resolution palaeoclimate reconstructions from North Africa for the 1st millennium, hampering a fully pan-Mediterranean reconstruction. In the absence of tree ring records for this period in the Mediterranean region, our analyses rely mostly on lake sediment and speleothem data. All of these proxies are presented in Figure 2; spatial hydro-climate variability on a centennial scale is shown in Figure 3.

From our numerical analyses of hydro-climate records, using the average z-scores per century, we can observe the following. Paired correlations reveal that, unsurprisingly, many of the records that correlate come from the same region (not shown in tables/graphs). However, few correlations $(21 \%)$ are statistically significant due to the small number of data points. The Principal Components Analysis (PCA) shows that PCA 

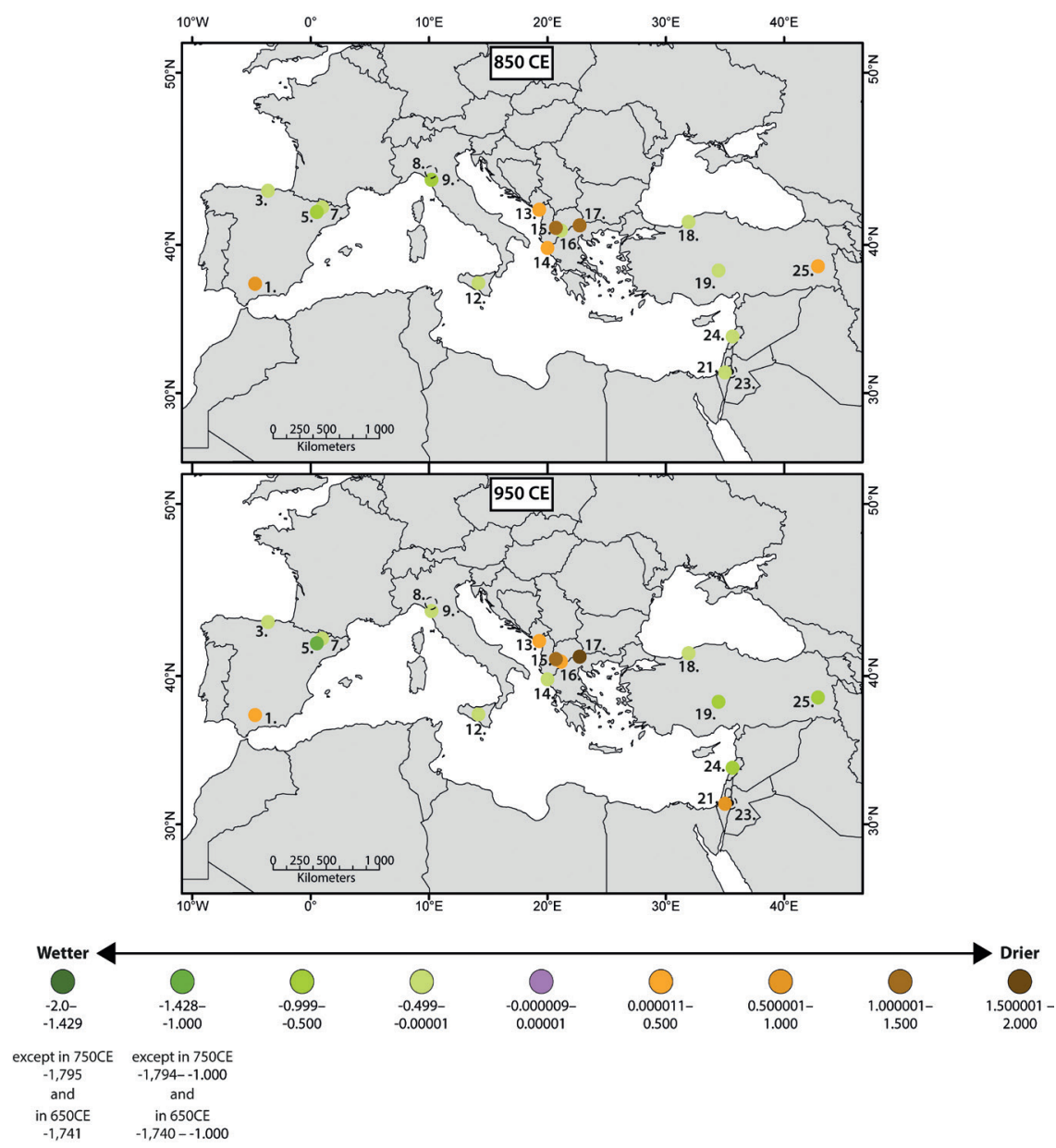

FIGURE 3 Average z-scores of each hydro-climate proxy record for each century. Negative values (green) reflect wetter than average conditions, positive value (brown) show drier conditions. Site numbers correspond to the numbers given in Table 1 (cont.).

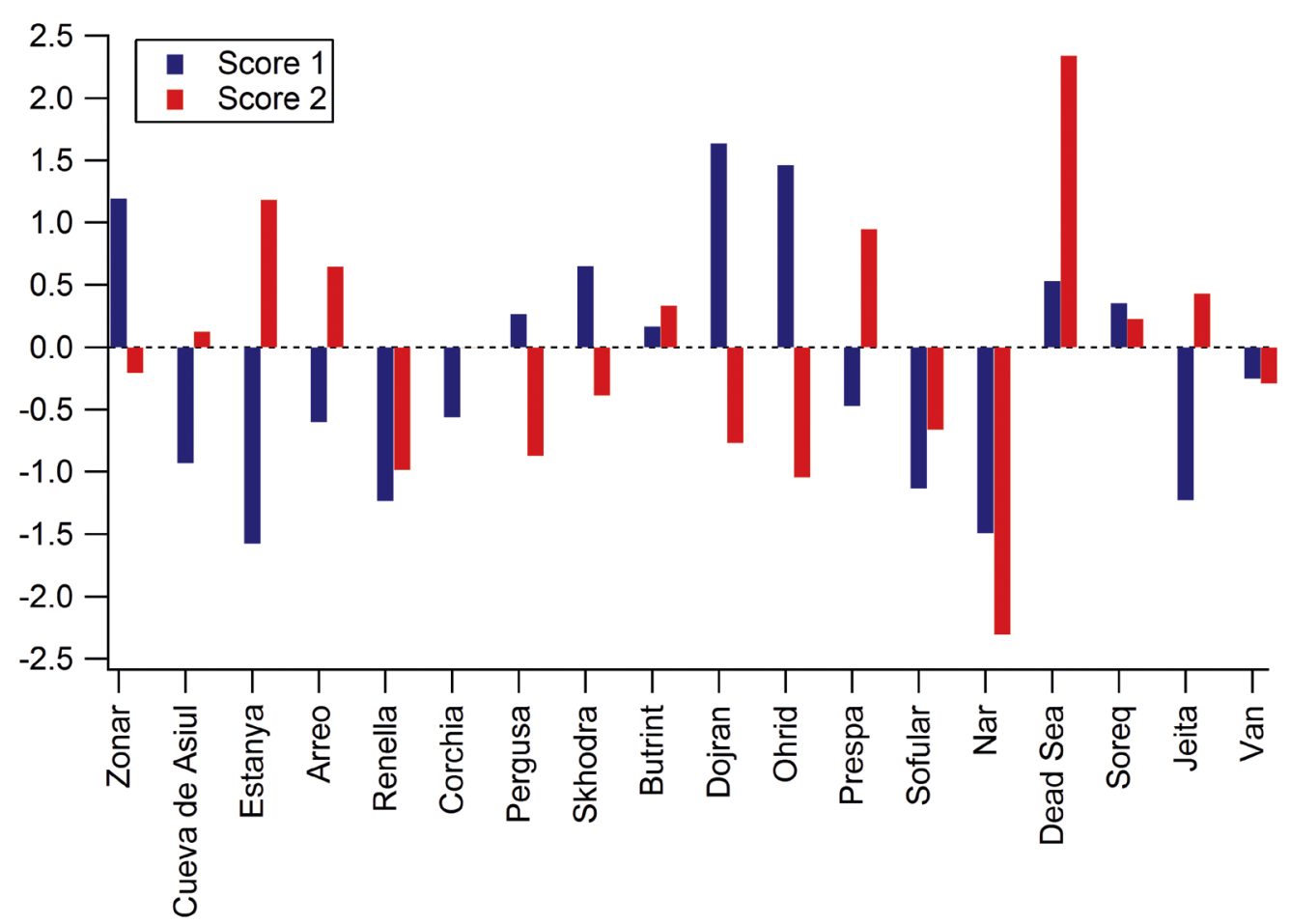

FIGURE 4 Results of the Principal Component Analysis (PCA) of hydro-climate proxies: values on Axis 1 and 2 for each hydro-climate proxy. Positive values reflect the degree to which a given proxy shares in the centennial dry/wet trends visible in Figure 5. The values for individual PCA axes are also presented on Figures 6 (Axis 1) and 7 (Axis 2). 

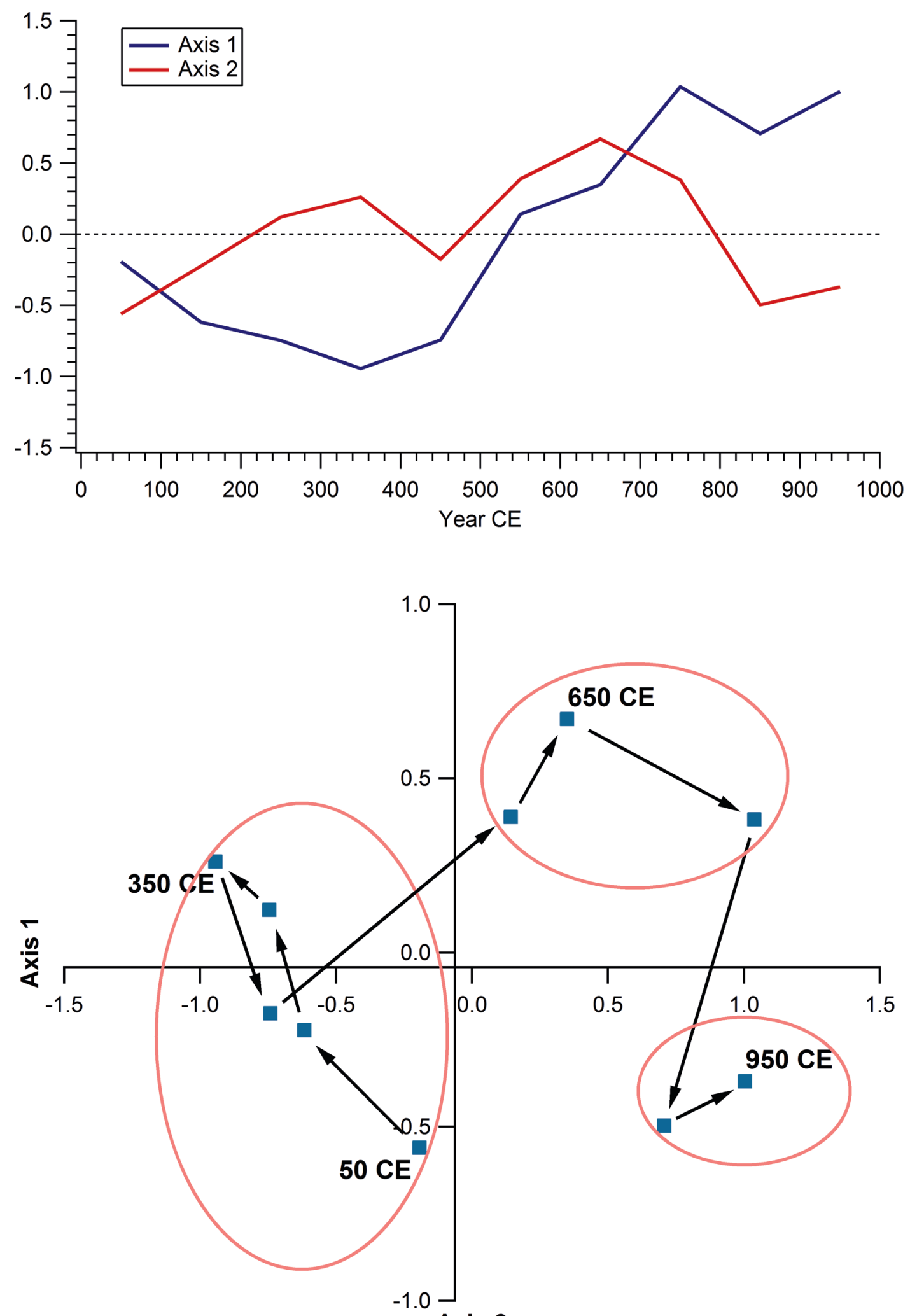

\section{Axis 2}

FIGURE 5 Results of the Principal Component Analysis (PCA) of hydro-climate proxies: values on Axis 1 and 2 per century. An increase in the axis value reflects a change toward drier conditions in proxies showing positive correlation with a given axis. 

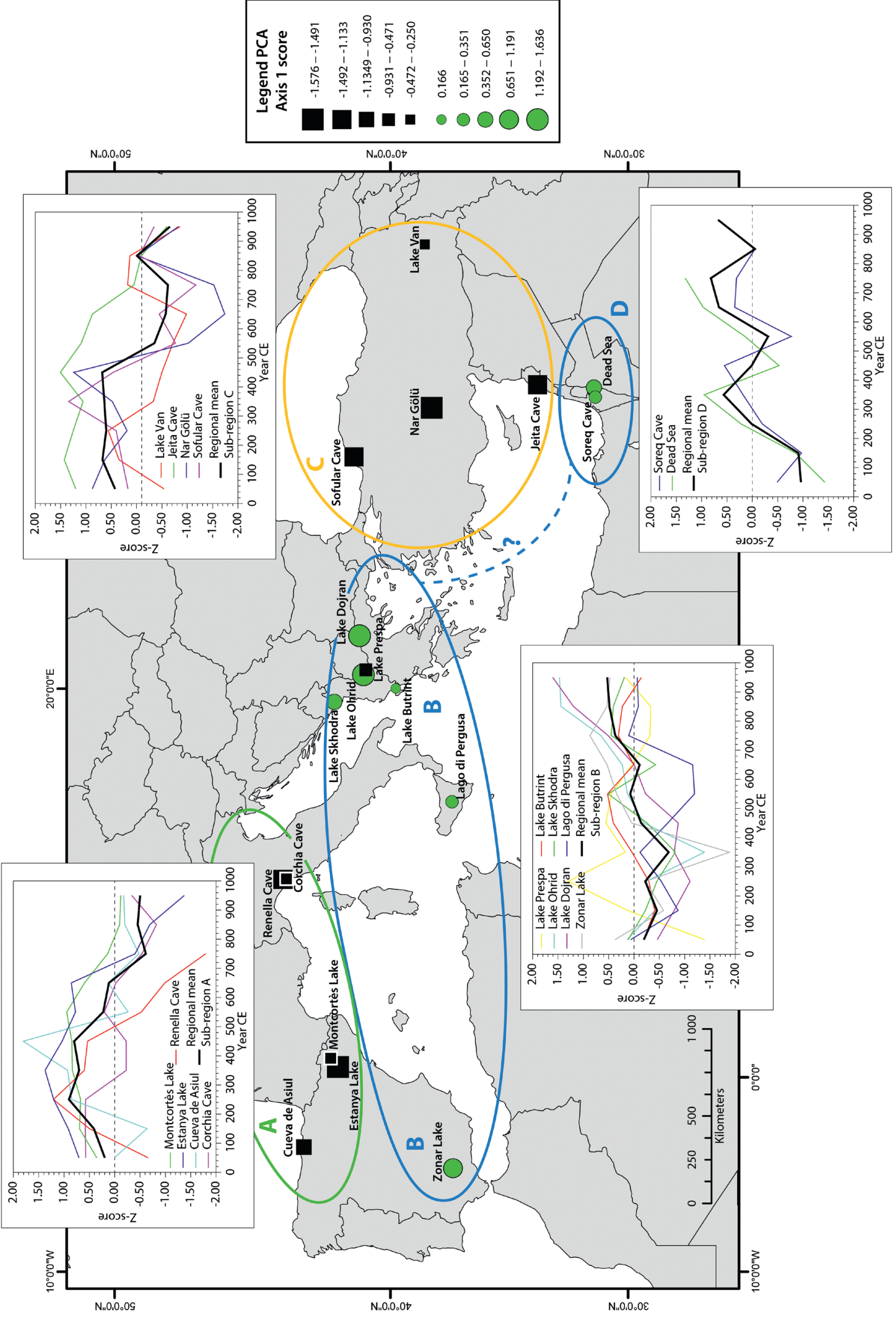



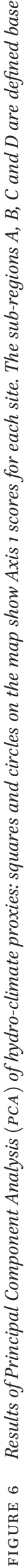


Axis 1 accounts for the majority (51\%) of the variance in the dataset. However, Axis 2 (16\% of variance) displays some interesting spatial patterns for time periods different from Axis 1 (figs 4 and 5). The results from the PCA suggest that four palaeoclimate sub-regions can be identified in the Mediterranean during the 1st millennium AD based on similar Axis 1 scores of the sites, namely:

a) Northern Iberia and northern Italy

b) Southern Iberia, southern Italy, the Balkans and northern Greece

c) the Anatolian peninsula and northern Levant

d) Southern Levant (fig. 6).

Coherence in the sub-regions is generally strong, although the timing of climate shifts may differ slightly between records.

\section{a) Northern Iberia and Northern Italy}

A common trend in the climate development of the Iberian Peninsula and northern Italy can be identified based on the Z-scores for the proxy records identified to belong to this sub-region (fig. 6). It shows that overall drier conditions in this sub-region during the early centuries AD were replaced by wetter conditions after ca. 500 .

A multiproxy record from Estanya lake in NE Spain has been interpreted to reflect lake levels relating to aridity. Lake levels remain low throughout most of the study period, but around 750 the lake level rose and runoff increased in the area, indicating wetter conditions. ${ }^{56}$ A geochemical record from Lake Montcortès, close to Estanya, shows increased runoff into the lake around 700, linked to increased precipitation as well as human land use in the area. ${ }^{57}$ Further, a geochemical record from nearby Arreo lake ${ }^{58}$ (not included in our numerical analysis) support progressively developing wetter conditions from around 8oo. Stable oxygen isotopes from stalagmites from Cueva de Asiul in northern Spain, indicate a drier period from 50 BC until AD 500, followed by fluctuating, but mainly wetter, conditions during the rest of the 1st millennium $\mathrm{AD} .{ }^{59}$ Stable oxygen isotopes from speleothems from the Renella and Corchia caves in NW Italy (which are located very close to each other) show an broadly similar pattern, with a trend towards wetter conditions from around $\mathrm{AD} 500,{ }^{60}$ in common with the records from northern Iberia.

b) Southern Iberia, Southern Italy, the Balkans and Northern Greece

Judging from the $\mathrm{z}$-scores of the records included in this sub-region the climate generally seems to have been wetter during the first half of the 1st millennium. This is contrary to the conditions prevailing in northern Iberia and northern Italy (sub-region A). Following the wetter start, most records show a trend towards more arid conditions from around 600 .

The $\mathrm{Rb} / \mathrm{Al}$ geochemical record from Zoñar Lake in southern Spain, interpreted to indicate runoff, shows overall wetter conditions until around AD 350, when drier conditions develop, a situation that remains throughout the 1st millennium. ${ }^{61}$ The $\delta^{18} \mathrm{O}$ record from Lago di Pergusa, suggests that conditions were generally wetter in this area in the first part of the millennium; they get particularly wet in the period $c a .400-600$, following a very brief drier start to the millennium. ${ }^{62}$ After 650-700, drier conditions develop in Sicily, as in the Balkans.

The laminated sediment record from Lake Butrint, a coastal lagoon in Albania, has been analysed at high resolution for elemental chemistry. ${ }^{63}$ Concentrations of strontium (and also the Sr/Ca ratio) show high values, indicating strong evaporation and climatic aridity between $c a$. $500 \mathrm{BC}$ and $\mathrm{AD} 30$, and again after 9oo, but rather stable moist conditions in between these times. Further north along the Adriatic coast, cores from Lake Skhodra (Skutari) have been analysed for stable isotopes and pollen. ${ }^{64}$ The $\delta^{18} \mathrm{O}$ data from Lake Skhodra show generally wetter conditions until around 6oo, when drier conditions start to develop.

Inland, on the Albania-Macedonia border, $\delta^{18} \mathrm{O}$ have been analysed in sediments from the adjacent Prespa and Ohrid lakes. ${ }^{65}$ Both records indicate wet hydroclimatic conditions at the start of the 1st millennium $\mathrm{AD}$, with Ohrid showing a gradual drying trend after $c a$. $\mathrm{AD} 300$, in line with the other records in this subregion. However, the $\delta^{18} \mathrm{O}$ record from Prespa, hydrologically the more responsive of the two lakes, also differ from other nearby records from this area (fig. 6). For instance, a short-lived drought is recorded during the

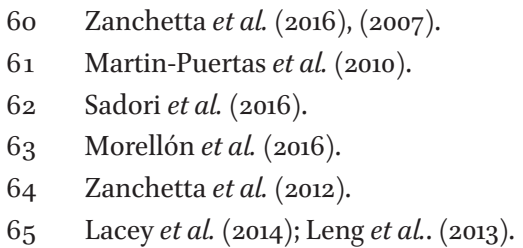


2nd and 3rd c. AD followed by seemingly stable, wetter conditions. It could thus be viewed as anomalous in relation to the other records in this sub-region. The potential reasons behind the anomalous behaviour of this proxy record are not fully understood, but it may be due to, for example, poor chronological control, non-climatic effects on the lake, or the proxy and threshold effects. Further inland, a geochemical record from Lake Dojran shows a similar picture to the other records from this sub-region, with an overall wetter start to the 1st millennium AD. From around 550 drier conditions develop at this site. 66

Two speleothem based $\delta^{18} \mathrm{O}$ records from southern mainland Greece suggest that this area also may belong to this sub-region. The $\delta^{18} \mathrm{O}$ record from Kapsia Cave, in the central Peloponnese, indicate a dry start to the 1st millennium, followed by a brief interval of wetter conditions around 200 . The wetter conditions are then replaced by an overall drying trend, evident throughout the rest of the ist millennium period. ${ }^{67}$ The indications from Kapsia are supported by a $\delta^{18} \mathrm{O}$ record from the nearby Alepotrypa Cave, located in the southern Peloponnese. ${ }^{68}$ This record, however, suggests that there might be an interval of wetter conditions in the late 6 th and the 7th c. AD, matching the records from NW and central Anatolia. Stalagmites in both Alepotrypa and Kapsia stop forming around 900 .

This sub-region may also have extended to include SW Turkey, since the stable isotope record from Gölhisar shows an overall drying trend during the 1st millennium AD. ${ }^{69}$

\section{c) Anatolian Peninsula and Northern Levant}

From the z-scores of the records in this sub-region, it seems that the climate was dominated by drier conditions until around AD 500, when wetter conditions start to develop (fig. 6). More precisely, the stable isotope records from Sofular Cave $\left(\delta^{13} \mathrm{C}\right)^{70}$ and Nar Lake $\left(\delta^{18} \mathrm{O}\right)^{71}$ (NW and central Anatolia respectively), show closely aligned trends throughout the ist millennium. During the later $4^{\text {th }}$ and early $5^{\text {th }} \mathrm{c}$., more pronounced drier conditions are recorded, followed by greater humidity during the later 6th, 7 th, and early 8th c.; a shorter-lived dry phase occurs afterwards. The same pattern is recorded in the less detailed sedimentary record from Tecer

\footnotetext{
66 Francke et al. (2013).

67 Finné et al. (2014).

68 Boyd (2015).

69 Eastwood et al. (2007).

$70 \quad$ Fleitmann et al. (2009).

71 Jones et al. (2006); Dean et al. (2013).
}

Lake. ${ }^{72}$ These trends are also in good accord with documentary evidence of droughts and floods in Anatolia during the same time period. ${ }^{73}$

The $\delta^{18} \mathrm{O}$ record from Lake Van (eastern Anatolia) ${ }^{74}$ has a similar general trend as the other records from the Anatolian peninsula, with conditions going from drier to wetter. However, here, this trend seems to start already in the 3 rd c., earlier than in the other records from the sub-region. This offset may, however, largely be related to chronological problems with the Lake Van record. ${ }^{75}$

In common with the records from $\mathrm{NW}$ and central Anatolia, the stalagmite based $\delta^{18} \mathrm{O}$ record from Jeita Cave (Lebanon) shows overall drier conditions until around $65^{\circ}$, when there is a turn towards wetter conditions, suggesting that this sub-region may also have extended into the northern Levant. The record from Jeita terminates around $800 .{ }^{76}$

\section{d) Southern Levant}

The calculated z-scores for Soreq Cave and the Dead Sea indicate two transitions from wetter to drier conditions during the 1st millennium AD. The first transition takes place during the first four centuries of the millennium, the second starts with wetter conditions around $45^{\circ}-55^{\circ}$, that are followed by gradually developing drier conditions until the end of the study period (fig. 6). The climate records from the southern Levantthat is, the Soreq Cave $\delta^{18} \mathrm{O}$-record ${ }^{77}$ and the Dead Sea lake level record ${ }^{78}$ - share common overall trajectories. This equates to wetter conditions during the first two centuries $\mathrm{AD}$, a subsequent drying trend, followed by a second wet phase in the mid ist millennium AD, before renewed desiccation during early medieval times. However, the timing of these changes varies slightly between the sites. The mid ist millennium wet phase, for example, is dated to the $5^{\text {th }} \mathrm{c}$. in the Dead Sea lake level record, and to $c a .500$ at Soreq cave. In reality, it is most likely that these differences are related to chronological imprecision; for example, Soreq is dated by U-Th ages within a standard error no better than \pm 110 years. ${ }^{79}$ There is greater consistency in the age estimates for early medieval climatic desiccation, namely between the mid 7 th and late 8th c.

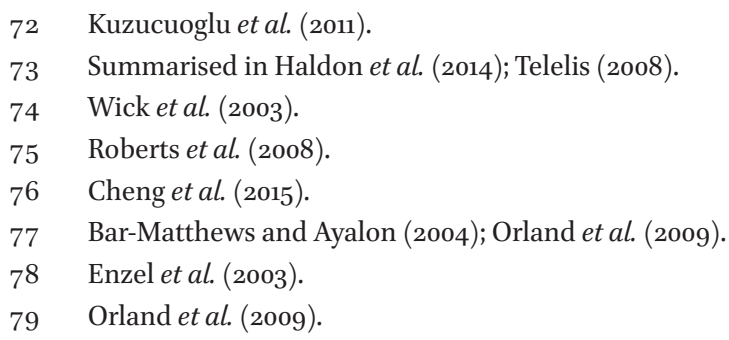




\section{Inter-Regional Comparisons}

The above outlined sub-regions show strong internal spatio-temporal coherency, but between the subregions there are both similarities and differences (fig. 6). This means that sites located close to each other often show a similar climate history, whereas over larger areas the situation is more complex. The different climate trajectories of the sub-regions imply that, as during the 2nd millennium $\mathrm{AD},{ }^{80}$ the Mediterranean as a whole did not experience a common history of climate prior to AD 1000. Nor was the pattern of change in climate in the Mediterranean the same as it was in areas of temperate Europe to the north. This is highlighted by the contrasting trends in inferred precipitation in central Europe and the Mediterranean between $c a$. 300-700. Whereas central Europe was notably wet at $c a .400,{ }^{81}$ many sites in the Mediterranean experienced dry conditions at this time, including many in sub-regions A, C and D. By the 6th c., central Europe became drier, while inferred precipitation increased in sub-regions $\mathrm{A}$ and $\mathrm{C}$, and remained relatively high in sub-region $\mathrm{B}$. This implies that shifts in atmospheric circulation alternately moved the predominant depression tracks northwards away from the Mediterranean or southwards towards it, possibly linked to Atlantic climate dynamics, tropical/extratropical interactions, as well as different influences from the Arabian Peninsula and Eurasia. Teleconnections, including the north-west to south-east see-saw, evident in the Mediterranean after 9oo, are more difficult to detect. Nonetheless, it is clear that north-western parts of the Mediterranean — northern Iberia and northern Italyas well as Anatolia and the northern Levant, experienced a different and opposite hydro-climatic trajectory to the central and southern parts of the western and eastern Mediterranean-southern Iberia, southern Italy, the Balkans, Greece and the southern Levant-during the 1st millennium AD. Some areas becoming wetter at the same time as other areas became drier, would have had potential implications for late antique societal development, for example, in terms of agrarian economies and water supplies.

Results of the PCA through time (fig 5) reflect a multi-centennial trend towards either wetter (subregions $\mathrm{A}$ and $\mathrm{C}$ ) or drier (B and $\mathrm{D})$ climatic conditions, via PCA axis 1 (higher values on either axes reflect drier conditions). The biggest climate shift during the 1st millennium occurs between the $5^{\text {th }}$ and the 6 th c. (Axis 1), but there is also a transition in the climate between the 8th and the gth c. (Axis 2). Thus, we can recognise three main hydro-climatic phases during the 1st millennium $\mathrm{AD}$, namely:

i) 1 st -4 th $\mathrm{c}$.

ii) $5^{\text {th }}-8$ th $\mathrm{c}$.

iii) 8 th-1oth $\mathrm{c}$.

What our analysis cannot show is the precise timing of climate change between century-long averages. The change in hydro-climate between the $5^{\text {th }}$ and 6 th c., evident in our numerical analysis, occurs closely in time to the $\mathrm{AD} 536$ 'dust veil' event. However, the resolution in our data does not allow a direct link between the two to be established. At the same time, it is worth noticing that individual sites show different correlations with each axes (fig. 4), which reflects the degree to which either the mid millennium or early/late transitions are most clearly reflected in each of the hydro-climate proxies. Proxies showing positive Axis 1 or 2 values in Figure 5 share trends toward drier/wetter conditions, as shown in Figure 6 (higher/lower values). ${ }^{82} \mathrm{~A}$ brief visual comparison makes clear that, despite the existence of these major centennial trends, individual proxies may be only weakly correlated with each other, resulting in a large degree of both inter- and intra-regional variability in precipitation/drought patterns.

\section{Implications for History and Archaeology}

Perhaps the most important conclusion emerging from this paper is that the Roman experience of climatic change in the Mediterranean was never the same. Geographical configuration, direction and scale of change were different in each period of antiquity, typically two to four centuries long, and this lack of a repeatable pattern continued into the first centuries of the Middle Ages. Superimposed on these multicentennial periods were much shorter annual to decadal hydro-climatic variations, which cannot be discerned from our synthetic multi-site comparison. Given that these shifting patterns of climatic change were superimposed on the dynamic political, cultural and economic texture of the Roman and post Roman world, researchers interested in disentangling the role of climate on the Mediterranean history of the ist millennium AD, should first of all concentrate on specific regions; the societal impact of climatic change, after all, is always a bottomup phenomenon. At the same time, we also hope to

82 Cf. Figures $3 \mathrm{a}-\mathrm{c}$, showing whether drier or wetter conditions prevailed in each proxy in a given century.
$80 \quad$ Roberts et al. (2012).

81 Büntgen et al. (2011). 


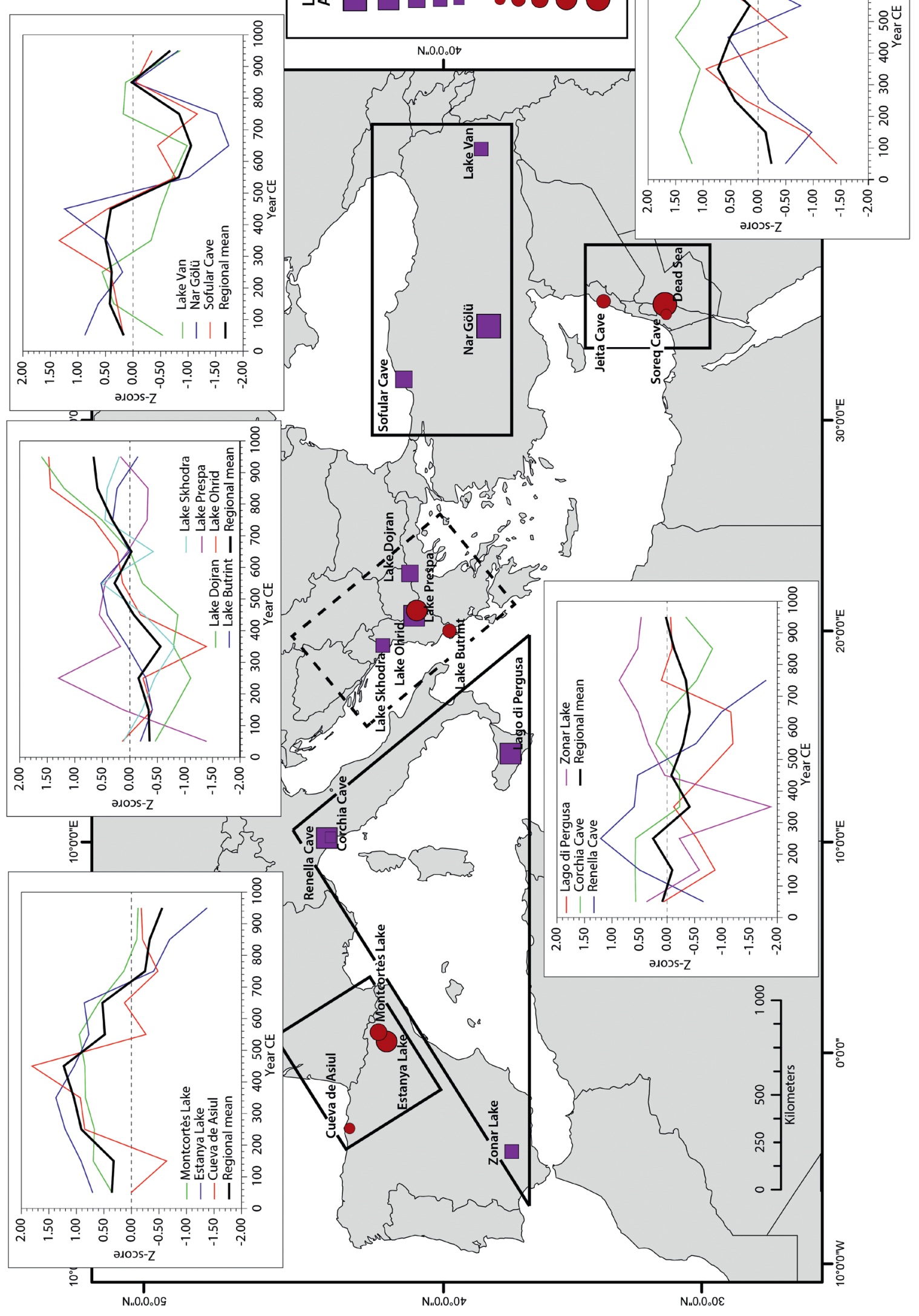

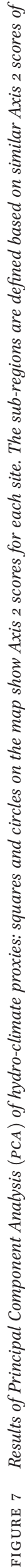


facilitate access to existing palaeoclimate proxies for the historical and archaeological communities.

In the following few paragraphs, the discussion will focus on the implications of the scale of spatio-temporal variability of climatic change in the 1st millennium AD. Mediterranean, for historical and archaeological research. While by no means do we aim at exhausting this immense topic, our brief discussion will sketch potential directions for future research, and will show the ways in which our findings could be integrated into mainstream historical narratives. We focus on the hydro-climate proxies, which are more numerous, and available from most of the Mediterranean; they also show greater variability. At the same time, it should be emphasised that recent work on temperature reconstructions for Europe and northern Eurasia support the idea of warmer conditions generally prevailing during the first centuries of Roman rule in the Mediterranean. This must have facilitated the expansion of the Mediterranean-style model of intensive, mixed agriculture across the empire. ${ }^{83}$ However, it should also be emphasised that the hydroclimate conditions were not that stable, and actually the same warm centuries saw drier conditions in many parts of the Mediterranean (see figs $3 \mathrm{a}-\mathrm{c}$ ), even if climate change throughout the first half of the millennium was more gradual than the second half.

The results of our PCA (figs 4-5, mapped on the Mediterranean on figs 6-7) provide insights into the spatial patterning of the Mediterranean experience of (hydro-)climatic change in the 1st millennium AD. Figure 6 shows major 'periods' of change in hydroclimatic conditions in the Mediterranean, mainly centred on $c a .500-600$ (Axis 1, the most significant change in the entire millennium), and 700-800 (again Axis 2); in addition, there also occurred a more gradual change throughout the first half of the millennium (mostly on Axis 2). On the Mediterranean scale, only three relatively small regions show repeatable spatial patterns for all the three major periods of climatic change. In other words, hydro-climate proxy records coming from these regions are always correlated, regardless of whether the change occurs on Axis 1 or 2. These are: northern Spain (3 records), Anatolia (3 records), and the southern Levant/Palestine (2 records). Other spatial correlations that concern hydro-climatic change within the Mediterranean are much less consistent, as geographic patterns vary from one period to another; this applies to: southern Spain and Italy (both north and south), the central Balkans, and northern Levant. If we consider these patterns in the context of economic or social history, it means that, depending on the specific time period, different parts of the Roman world were experiencing climatic stresses of a different nature in terms of both direction of change (wetter/drier) and severity (magnitude).

For the first five centuries of the 1st millennium AD, we can identify a notable increase in the PCA Axis 2 values, and a slight decline in Axis 1. In general, this amounted to a long-term aridification trend, relatively widespread in the Mediterranean, although showing some notable exceptions. In the Levant and northern Spain, there is indeed a clear trend toward drier conditions from the 2nd c. AD onward, culminating in the 4th c., although in northern Spain it is of lesser severity, except for the north (Atlantic) coast. This drying trend is also visible in Italy, although in this region it is no longer present after the 3 rd c., which means it was of shorter duration. We also see the drying trend in Anatolia, although here a major period of drier conditions occurred later, in the 4 th -5 th $\mathrm{c}$. At the same time, most of the Balkans, southern Iberia and, to a lesser extent, Palestine, experience wetter conditions. Importantly, the $c a$. AD 50-450 drying trend in a number of key regions of the Mediterranean (Iberia, Italy, Anatolia) is synchronous with the beginning of the long-term cooling trend visible in most of the temperature proxies in the Mediterranean (see fig. 1). Taken together, these two climatic phenomena-drying and cooling - could amount to serious environmental stress for Roman agriculture and the Roman economy, in particular in the core areas of the West. Lower temperatures would have shortened the vegetation season, while a decrease in precipitation (or a higher frequency of extreme events, such as droughts) would reduce the productivity and long-term reliability of agriculture in these Mediterranean regions.

Strikingly, the most widespread phase of this 'Roman drying trend' coincides with the so-called '3rd c. crisis' of the Roman empire, which involved both political instability and major warfare, as well as associated financial problems and economic decline in some of the provinces. ${ }^{84}$ Moreover, the same period (late 2nd-mid 3rd c.) offers abundant evidence for intense epidemic disease. ${ }^{85}$ However, attributing any causality in this primarily military-political crisis to climatic change would first require undertaking a careful comparison of local palaeoclimate proxies with regional textual and archaeological evidence for climate-related phenomena, such as harvest failures, more permanent agricultural and settlement transformations, or shifts in disease ecologies.

The geographical pattern of the most important climatic change of the 1st millennium AD, which occurred

\footnotetext{
84 Duncan-Jones (2004); Witschel (2004); Ziółkowski (2011).

85 See Harper in this volume.
}

Downloaded from Brill com05/16/2019 12:49:10PM 
around the middle of our study period, and is reflected in Axis 1, hints at how careful we should be when it comes to any spatial generalisations of hydro-climatic change in the Mediterranean. This also applies, consequently, with making any direct links between macro-structural developments in Late Roman society, state, or economy, and climate. Out of our four Axis 1 macro-regions, two show persistent trends towards wetter conditions: northern Iberia-northern Italy and Anatolia-northern Levant; there are sites in the West, however, that show very little or almost no such trend at all. In terms of the two regions that ultimately experienced transition to drier conditions, the southern Levant shifted toward drier conditions only after a century-long wet interlude in the 6th c., while in the central Mediterranean, Sicily experienced significantly wetter conditions well into the 7 th c., despite showing a long-term drying trend that it shares with some southern-central Mediterranean sites in southern Iberia and the Balkans.

This period of climatic history of the Mediterranean, which coincides with the formative centuries of Late Antiquity, has been much better investigated, and there exists a number of hypotheses about the impact of climatic change on the course of societal and political transformations. It is worth pointing out, however, that as research advanced, these hypotheses have become less general and more regionally specific. ${ }^{86}$ While little evidence has been found for the damaging impact of the prolonged drier conditions in many parts of the Mediterranean (including the 4 th -5 th $\mathrm{c}$. drought in Anatolia and the Levant), it has been argued, for instance, that the subsequent shift toward wetter conditions either facilitated or encouraged agricultural and rural settlement expansion on new lands, in Sicily, Anatolia, and the Levant. It has also been argued that the increased humidity further aggravated the crisis endured by Roman agriculture in the West. There has also been a growing interest in the economic stress resulting from changes in the frequency of harvest failures, in particular in the context of the 6th c. cooling. ${ }^{87}$ Altogether, these different studies demonstrate how regional-scale investigations make it possible to understand the complicated interplay between climate and society in the Roman and post Roman world, a phenomenon that increasingly appears to be irreducible to simple models of climate-related collapse or a climate optimum that guarantees economic (and political) success.

As we move to the final major period of climatic change in the 1st millennium $\mathrm{AD}$, the economic and

Cf. Cheyette (2008), Izdebski (2011), or McCormick et al. (2012), with Haldon et al. (2014), Izdebski et al. (2016), or Sadori et al. (2016).

87 See the references in Büntgen et al. (2016). political geography undergoes significant changes. Unlike in the earlier periods, as the new empires and kingdoms become reduced in size, for the first time there is an overlap between a climatic region-a large part of the Mediterranean that experiences a similar trajectory of climatic change - and the core areas of a political organism. Around 70o, all that remained of the eastern Roman empire (from that moment on called 'Byzantine' in modern historiography) experienced a drying trend, most pronounced in Anatolia and in Sicily, with most of the Balkans having transitioned to a much drier regime already around 500-60o. Surprisingly, this shared trend did not mean shared impacts: Sicily is the only Byzantine province for which, it has been argued, the early medieval drying trend undermined the foundations of the region's agricultural prosperity. ${ }^{88}$ In the case of Anatolia, agriculture and rural settlement was already undergoing profound transformation that probably remained unaffected by the early medieval climatic change. ${ }^{89}$ At the same time, in the West, the wetter conditions achieved their climax and stabilised. ${ }^{90}$

Before concluding, it is worth emphasising once again the degree of spatial variability in patterns of hydro-climate variations across the Mediterranean of the 1st millennium AD. Different proxies show different amplitude of change; it suffices to contrast Butrint and Nar to realise the importance of this observation (see fig. 1). Each of them have their own proxy-specific 'portion' of temporal variability - unrelated to any of the axes from the PCA - that may indeed reflect entirely local variations in precipitation and individual proxies' sensitivity to climate. In comparison to previous syntheses of 'Roman' climate, our paper shows that the more data that are available, the more complex our understanding of Mediterranean palaeoclimate becomes, and the less justified our generalisations seem. At the same time, the more difficult it is to connect the complexities of Mediterranean climatic changes to our narrative of human history. Thus, the more data that become available, the better and more complex our knowledge becomes of 'Roman' climate change, and the easier it is to investigate the link between climatic variability and societal developments. Indeed, as this brief discussion has attempted to demonstrate, shifts in climatic conditions did not coincide in a straightforward way with major changes in political regimes, regional settlement histories, or economic patterns. Rather, climatic changes had

88 Sadori et al. (2016)

$89 \quad$ England et al. (2008); Izdebski (2013).

90 The early medieval experience of water has already attracted several medievalists' attention, without them, however, placing it in the context of a changing climate: Squatriti (1998). 
their own trajectories that were intertwined with societal dynamics in more subtle ways than one would initially expect. Consequently, chronologies derived from material culture and the written record-which focus on more 'traditional' moments of transition-are not necessarily capable of grasping the impact of climatic changes on Mediterranean history. If future research is to engage fully with this topic, it needs to reconsider existing chronologies, historical frameworks and approaches to the dating of major societal phenomena, in order to become capable of identifying genuine temporal correlations and, in the end, reconstructing potential causal connections.

\section{Concluding Remarks}

Many efforts to synthesise and integrate Mediterranean and European palaeoclimate reconstructions have recently been undertaken. ${ }^{91}$ However, this task remains challenging. In particular, the reconstruction of shortterm climate variability, as well as a comparison of records that allows the identification of regional patterns, are still restricted due to the limited number of proxies and the uncertainties related to chronologies, resolution, proxy sensitivity and seasonality.

There is great potential for increasing the temporal and spatial coverage of climate proxy data in the Mediterranean region during the ist millennium $\mathrm{AD}$, as well as increasing their resolution. The use of wood found in archaeological contexts may extend dendroclimatic reconstructions beyond the time spans they cover today, which would allow the study of the link between climate variability and societal developments on much finer temporal scales. ${ }^{92}$ Laboratory methods are improving, leading to potentially higher resolutions and greater analytical precision of proxy measurements, as well better chronological control, ${ }^{93}$ all of which are especially relevant for comparisons with historical and archaeological studies. Furthermore, monitoring studies, laboratory experiments and models lead to a better understanding of the chemical, biological and physical processes of archive formation, and proxy responses to climatic and non-climatic influences. These will ultimately lead to a more sound, and possibly more quantified, interpretation of proxy records in terms of climate.

Despite uncertainties in the data, we have been able to identify some clear and remarkably coherent

91 E.g. Cook et al. (2015); Finné et al. (2011); Izdebski et al. (2016); Luterbacher et al. (2012); PAGES 2k Consortium (2013). See Büntgen et al. (2011) as an example. (2009). multi-century hydro-climatic trends within four different sub-regions of the Mediterranean, namely: northern Iberia and northern Italy; southern Iberia, southern Italy, the Balkans and northern Greece; the Anatolian peninsula and northern Levant; and southern Levant. The resulting spatio-temporal patterns are not the same as those identified for the 2 nd millennium $\mathrm{AD},{ }^{94}$ implying that the underlying modes of climate change (such as the NAO) were not stable over time. PCA analysis indicates that the most important climate shift of the 1st millennium AD occurred between the $5^{\text {th }}$ and 6th c. (PCA axis 1). This may have coincided in time with the 'dust veil' event of 536 , which has been used as the start date of a 'Late Antique Little Ice Age' (536-ca. 66o). ${ }^{95}$ This period of low temperatures overlaps in time with the third multi-centennial hydro-climatic period identified in our study (ca. 500-ca. 700), which was marked by wetter than average climatic conditions in northern Iberia, central Italy and Anatolia, but by a more arid climate in most of the Balkans. This illustrates how there was no simple relationship between changes in temperature and precipitation in the past. Consequently, as we argue in this paper, exploring the links between climate change and human history requires a nuanced and complex approach, taking account of both the more general patterns of climate change and their sub-regional or even local expressions, as well as the regional trajectories of agricultural, economic, political and cultural changes.

\section{Acknowledgements}

The authors would like to thank those researchers who have contributed to the cited studies and made their data available, notably: Mario Morellon, Blas Valero-Garces, Giovanni Zanchetta, Jack Lacey, Melanie Leng, Dominik Fleitmann, Matt Jones, Jonathan Dean, Miryam BarMatthews, Hai Cheng, and Lucia Wick. Adam Izdebski would like to acknowledge funding from the Ministry of Science and Higher Education, Poland (National Programme for the Development of the Humanities, 2016-19). Martin Finné would like to acknowledge funding from the Swedish Research Council (grant number 421-2014-1181).

\section{Bibliography}

Baker A., Smith C., Jex C., Fairchild I. J., Genty D. and Fuller, L. (2008) "Annually laminated speleothems: a review", Internatioal Journal of Speleology 37 (2008) 193-206.

94 By Roberts et al. (2012).

95 Büntgen etal. (2016). 
Bar-Matthews M. and Ayalon A. (2004) "Speleothems as palaeoclimate indicators. A case study from Soreq Cave located in the eastern Mediterranean region, Israel", in Past Climate Variability through Europe and Africa, ed. R.W. Battarbee (Dordrecht 2004) 638. doi:10.1007/978-1-4020-2121-3.

Bard E., Raisbeck G., Yiou F. and Jouzel J. (2000) "Solar irradiance during the last 1200 years based on cosmogenic nuclides", Tellus $B 5^{2}$ (2000) 985-92: doi:10.1034/j.1600-0889.2000.do1-7.x.

Berger A. and Loutre M. F. (1991) "Insolation values for the climate of the last 10 million years”, Quaternary Science Reviews 10 (1991) 297-317.

Boyd M. (2015) Speleothems from Warm Climates Holocene Records from the Caribbean and Mediterranean Regions (Ph.D diss., Univ of Stockholm 2015).

Bradley R. S. (2015) Paleoclimatology. Reconstructing Climates of the Quaternary (San Diego 2015).

Büntgen U., Myglan V. S., Ljungqvist F.C. et al. (2016) “Cooling and societal change during the Late Antique Little Ice Age from 536 to around 66o AD", Nature Geoscience 9 (2016) 231-36. doi:10.1038/ ngeo2652.

Büntgen U., Tegel W., Nicolussi K. et al. (2011) “2500 years of European climate variability and human susceptibility”, Science 331 (2011) 578-82: doi:10.1126/science.1197175.

Catalan J., Ventura M., Brancelj A. et al. (2002) "Seasonal ecosystem variability in remote mountain lakes: implications for detecting climatic signals in sediment records", Journal of Paleolimnology 28 (2002) 25-46: doi:10.1023/A:1020315817235.

Cheng H., Lawrence Edwards R., Shen C.-C. et al. (2013) "Improvements in 230Th dating, 230Th and 234U half-life values, and U-Th isotopic measurements by multi-collector inductively coupled plasma mass spectrometry", Earth and Planetary Science Letters 371-72 (2013) 82-91: doi:10.1016/j.epsl.2013.04.0o6.

Cheng H., Sinha A., Verheyden S. et al. (2015) "The climate variability in northern Levant over the past 20,000 years", Geophysical Research Letters 42 (2013) 8641-50: doi:10.1002/2015GL065397.

Cheyette F. L. (2008) "The disappearance of the ancient landscape and the climatic anomaly of the early Middle Ages: a question to be pursued", Early Medieval Europe 16 (2008) 127-65: doi:10.1111/j.1468-0254.2008.00225.x.

Christiansen B. and Ljungqvist F. C. (2017) "Challenges and perspectives for large-scale temperature reconstructions of the past two millennia", Reviews of Geophysics 55 (2017) 40-96: doi:10.1002/2016RGooo521.

Cook B. I., Anchukaitis K. J., Touchan R., Meko D. M. and Cook E. R. (2016) "Spatiotemporal drought variability in the Mediterranean over the last 900 years", Journal of Geophysical Research: Atmospheres 121 (2016) 2060-74: doi:10.1002/2015JDo23929.

Cook E. R. and Kairiukstis L. A. (1990) Methods of DendrochronologyApplications in the Environmental Sciences (Dordrecht 1990).

Cook E. R., Seager R., Kushnir Y. et al. (2015) "Old World megadroughts and pluvials during the Common Era”, Science Advances 1 (2015) e1500561-e1500561: doi:10.1126/sciadv.1500561.

Corella J. P., Moreno A., Morellón M., Rull V., Giralt S., Rico M. T., PérezSanz A. and Valero-Garcés B. L. (2011) "Climate and human impact on a meromictic lake during the last 6,00o years (Montcortès Lake, Central Pyrenees, Spain)", Journal of Paleolimnology 46 (2011) 351-67: doi:10.1007/s10933-010-9443-3.

Corella J. P., Stefanova V., El Anjoumi A., Rico E., Giralt S., Moreno A., Plata-Montero A. and Valero-Garcés B. L. (2013) “A 2500-year multi-proxy reconstruction of climate change and human activities in northern Spain: the Lake Arreo record", Palaeogeography Palaeoclimatology Palaeoecology 386 (2013) 555-68: doi:10.1016/j. palaeo.2013.06.022.

Corte-Real J., Zhang X. and Wang X. (1995) "Large-scale circulation regimes and surface climatic anomalies over the Mediterranean",
International Journal of Climatology 15 (1995) 1135-50: doi:10.1002/ joc.3370151006.

Cullen H. M. and de Menocal P. B. (2000) "North Atlantic influence on Tigris-Euphrates streamflow", International Journal of Climatology 20 (2000) 853-63: doi:10.1002/1097-0088(20000630)20:8<853::AIDJOC497>3.0.CO;2-M.

Dean J. R., Jones M. D., Leng M. J. et al. (2013) "Palaeo-seasonality of the last two millennia reconstructed from the oxygen isotope composition of carbonates and diatom silica from Nar Gölü, central Turkey", Quaternary Science Reviews 66 (2013) 35-44: doi:10.1016/j.quascirev.2012.07.014.

Dermody B. J., De Boer H. J., Bierkens M. F. P., Weber S. L., Wassen M. J. and Dekker S. C. (2012) "A seesaw in Mediterranean precipitation during the Roman period linked to millennial-scale changes in the North Atlantic", Climate of the Past 8 (2012) 637-51: doi:10.5194/cp-8-637-2012.

Donohoe A. and Battisti D. S. (2011) "Atmospheric and surface contributions to planetary albedo", Journal of Climate 24 (2011) 4402-18: doi:10.1175/2011JCLI3946.1.

Duncan-Jones R. (2004) "Economic change and the transition to Late Antiquity", in Approaching Late Antiquity: the Transformation from Early to Late Empire, edd. S. Swain and M. Edwards (Oxford 2004) 20-52.

Eastwood W. J., Leng M. J., Roberts N. and Davis B. (2007) "Holocene climate change in the eastern Mediterranean region: a comparison of stable isotope and pollen data from Lake Gölhisar, southwest Turkey", Journal of Quaternary Science 22 (2007) 327-41: doi:10.1002/jqs.1062.

England A., Eastwood W. J., Roberts C. N., Turner R. and Haldon J. F. (2008) "Historical landscape change in Cappadocia (central Turkey): a palaeoecological investigation of annually laminated sediments from Nar lake", The Holocene 18 (2008) 1229-45: doi:10.1177/0959683608096598.

Enzel Y., Bookman R., Sharon D., Gvirtzman H., Dayan U., Ziv B. and Stein M. (2003) "Late Holocene climates of the Near East deduced from Dead Sea level variations and modern regional winter rainfall", Quaternary Research 60 (2003) 263-73: doi:10.1016/j. yqres.2003.07.011.

Felis T. and Rimbu N. (2010) "Mediterranean climate variability documented in oxygen isotope records from northern Red Sea corals - a review", Global and Planetary Change 71 (2010) 232-41: doi:10.1016/j.gloplacha.2009.10.006.

Finné M., Bar-Matthews M., Holmgren K., Sundqvist H. S., Liakopoulos I. and Zhang Q. (2014) "Speleothem evidence for Late Holocene climate variability and floods in Southern Greece", Quaternary Research 81 (2014) 213-27: doi:10.1016/j.yqres.2013.12.009.

Finné M., Holmgren K., Sundqvist H. S., Weiberg E. and Lindblom M. (2011) "Climate in the eastern Mediterranean, and adjacent regions, during the past 6000 years - a review", JAS 38 (2011) 315373: doi:10.1016/j.jas.2011.05.007.

Fleitmann D., Cheng H., Badertscher S. et al. (2009) "Timing and climatic impact of Greenland interstadials recorded in stalagmites from northern Turkey", Geophysical Research Letters 36 (2009) 1-5: doi:10.1029/2009GL040050.

Francke A., Wagner B., Leng M. J. and Rethemeyer J. (2013) "A Late Glacial to Holocene record of environmental change from Lake Dojran (Macedonia, Greece)", Climate of the Past 9 (2013) 481-98: doi:10.5194/cp-9-481-2013.

Frisia S., Borsato A., Spötl C., Villa I. and Cucchi F. (2005) "Climate variability in the SE Alps of Italy over the past 17000 years reconstructed from a stalagmite record", Boreas 34 (2005) 445-55: doi:10.1080/03009480500231336.

Fritts H. C. and Guiot J. (1990) "Methods of calibration, verification, and reconstruction", in Methods of DendrochronologyApplications in the Environmental Sciences, edd. E. R. Cook and L. A. Kairiukstis (Dordrecht 1990) 163-217. 
Gildor H. and Ghil M. (2002) "Phase relations between climate proxy records: potential effect of seasonal precipitation changes", Geophysical Research Letters 29 (2002) 1-4: doi:10.1029/2001GLo13781.

Göktürk O. M. (2011) Climate in the Eastern Mediterranean through the Holocene Inferred from Turkish Stalagmites (Ph.D. diss., Univ. of Bern 2011).

Göktürk O. M., Fleitmann D., Badertscher S. et al. (2011) "Climate on the southern Black Sea coast during the Holocene: implications from the Sofular Cave record", Quaternary Science Reviews 30 (2011) 2433-45: doi:10.1016/j.quascirev.2011.05.007.

Haldon J., Roberts N., Izdebski A. et al. (2014) "The climate and environment of Byzantine Anatolia: integrating science, history, and archaeology", Journal of Interdisciplinary History 45 (2014) 113-61: doi:10.1162/JINH.

Hays J. D., Imbrie J. and Shackleton N. J. (1976) "Variations in the earth's orbit: pacemaker of the Ice Ages”, Science 194 (1976) 112132: doi:10.1126/science.194.4270.1121.

Hoffmann D. L., Spötl C. and Mangini A. (2009) "Micromill and in situ laser ablation sampling techniques for high spatial resolution MC-ICPMS U-Th dating of carbonates", Chemical Geology 259 (2009) 253-61: doi:10.1016/j.chemgeo.2008.11.015.

Hua Q. (2009) "Radiocarbon: a chronological tool for the recent past”, Quaternary Geochronology 4 (2009) 378-90: doi:10.1016/j. quageo.2009.03.006.

Izdebski A. (2013) A Rural Economy in Transition: Asia Minor from Late Antiquity into the Early Middle Ages (Warsaw 2013).

Izdebski A. (2011) "Why did agriculture flourish in the late antique east? The role of climate fluctuations in the development and contraction of agriculture in Asia Minor and the Middle East from the 4 th till the 7 th c. AD. millenium", Jahrbuch Zu Kultur Und Geschichte Des Ersten Jahrtausends N. Chr. 8 (2011) 291-312.

Izdebski A., Pickett J., Roberts N. and Waliszewski T. (2016) "The environmental, archaeological and historical evidence for regional climatic changes and their societal impacts in the eastern Mediterranean in Late Antiquity", Quaternary Science Reviews 136 (2016) 189-208: doi:10.1016/j.quascirev.2015.07.022.

Jex C. N., Baker A., Fairchild I. J., Eastwood W. J., Leng M. J., Sloane H. J., Thomas L. and Bekaroğlu E. (2010) "Calibration of speleothem $\delta^{18} \mathrm{O}$ with instrumental climate records from Turkey", Global and Planetary Change 71 (2010) 207-17: doi:10.1016/j. gloplacha.2009.08.004.

Jones M. D., Roberts C. N., Leng M. J., Türkeş M. (2006) “A high-resolution Late Holocene lake isotope record from Turkey and links to North Atlantic and monsoon climate", Geology 34 (2006) 361: doi:10.1130/G22407.1.

Juggins S. (2014) C2 Data Analysis: version 1.7.6. Newcastle University (computer program).

Kuzucuoglu C., Dorfler W., Kunesch S. and Goupille F. (2011) "Mid- to Late-Holocene climate change in central Turkey: the Tecer Lake record", The Holocene 21 (2011) 173-88: doi:10.1177/o959683610384163.

Lacey J. H., Francke A., Leng M. J., Vane C. H. and Wagner B. (2014) "A high-resolution Late Glacial to Holocene record of environmental change in the Mediterranean from Lake Ohrid (Macedonia/ Albania)", International Journal of Earth Sciences 104 (2014) 162338: doi:10.1007/s00531-014-1033-6.

Larsen L. B., Vinther B. M., Briffa K. R. et al. (2008) "New ice core evidence for a volcanic cause of the AD 536 dust veil", Geophysical Research Letters 35 (2008) Lo4708: doi:10.1029/2007GL032450.

Leng M. J., Wagner B., Boehm A. et al. (2013) "Understanding past climatic and hydrological variability in the Mediterranean from Lake Prespa sediment isotope and geochemical record over the last glacial cycle", Quaternary Science Reviews 66 (2013) 123-36: doi:10.1016/j.quascirev.2012.07.015.

Lionello P., Malanotte-Rizzoli P., Boscolo R. et al. (2006) "The Mediterranean climate: an overview of the main characteristics and issues", Developments in Earth and Environmental Sciences 4 (2006) 1-26: doi:10.1016/S1571-9197(06)80003-0.

Lowe D. J. (2011) "Tephrochronology and its application: a review", Quaternary Geochronology 6 (2011) 107-53: doi:10.1016/j. quageo.2010.08.003.

Lowe J. J. and Walker M. J. C. (2015) Reconstructing Quaternary Environments (New York, 3rd edn. 2015).

Luterbacher J., García-Herrera R., Akcer-On S. et al. (2012) "Review of 2000 years of paleoclimatic evidence in the Mediterranean", in The Climate of the Mediterranean Region From the Past to the Future, ed. P. Lionello, (London-Waltham, Mass. 2012) 87-185: doi:http://dx.doi.org/10.1016/B978-0-12-416042-2.00002-1.

Luterbacher J., Werner J. P. and Smerdon J. E. (2016) "European summer temperatures since Roman times", Environmental Research Letters 11 (2016) 2-12: doi:10.1088/1748-9326/11/2/024001.

Mangini A., Spötl C. and Verdes P. (2005) "Reconstruction of temperature in the Central Alps during the past $2000 \mathrm{yr}$ from a $\delta^{18} \mathrm{O}$ stalagmite record", Earth and Planetary Science Letters 235 (2005) 741-51: doi:10.1016/j.epsl.2005.05.010

Martín-Chivelet J., Muñoz-García M. B., Edwards R. L., Turrero M. J. and Ortega A. I. (2011) "Land surface temperature changes in northern Iberia since $4000 \mathrm{yr} \mathrm{BP}$, based on [delta] $13 \mathrm{C}$ of speleothems", Global and Planetary Change 77 (2011) 1-12: doi:10.1016/j. gloplacha.2011.02.002.

Martín-Puertas C., Jiménez-Espejo F., Martínez-Ruiz F., NietoMoreno V., Rodrigo M., Mata M. P., Valero-Garcés B. L. (2010) “Late Holocene climate variability in the southwestern Mediterranean region: an integrated marine and terrestrial geochemical approach", Climate of the Past 6 (2010) 807-16: doi:10.5194/ cp-6-807-2010.

Masson-Delmotte V., Schulz M., Abe-Ouchi A. et al. (2013) "Information from paleoclimate archives", in Climate Change 2013: the Physical Science Basis. Contribution of Working Group I to the Fifth Assessment Report of the Intergovernmental Panel on Climate Change, edd. T. F. Stocker, D. Qin, G-K. Plattner et al. (CambridgeNew York 2013) 383-464.

McCormick M., Büntgen U., Cane M. A. et al. (2012) “Climate change during and after the Roman empire: reconstructing the past from scientific and historical evidence", Journal of Interdisciplinary History 43 (2012) 169-220: doi:10.1162/JINH_a_oo379.

Mitchell J. F. B. (1989) “The 'greenhouse' effect and climate change", Reviews of Geophysics 27 (1989) 115: doi:10.1029/RG027ioo1poo115.

Morellón M., Anselmetti F. S., Ariztegui D. et al. (2016) "Humanclimate interactions in the central Mediterranean region during the last millennia: the laminated record of Lake Butrint (Albania)", Quaternary Science Reviews 136 (2016) 134-52: doi:10.1016/j.quascirev.2015.10.043.

Morellón M., Valero-Garcés B., Vegas-Vilarrúbia T. et al. (2009) "Lateglacial and Holocene palaeohydrology in the western Mediterranean region: the Lake Estanya record (NE Spain)", Quaternary Science Reviews 28 (2009) 2582-99: doi:10.1016/j. quascirev.2009.05.014.

Newfield T. P. (2018) "The climate downturn of $535^{-550 ", ~ i n ~ T h e ~}$ Palgrave Handbook of Climate History, edd. S. White, C. Pfister and F. Mauelshagen (2018), 447-493: doi:10.1057/978-1-137-43020-5_32. Orland I. J., Bar-Matthews M., Kita N. T., Ayalon A., Matthews A. and Valley J. W. (2009) "Climate deterioration in the eastern Mediterranean as revealed by ion microprobe analysis of a speleothem that grew from 2.2 to 0.9 ka in Soreq Cave, Israel", Quaternary Research 71 (2009) 27-35: doi:10.1016/j.yqres.2008.08.005.

PAGES 2k Consortium (2013) "Continental-scale temperature variability during the past two millennia", Nature Geoscience 6 (2013) 339-46: doi:10.1038/NGEO1797.

Pla S. and Catalan J. (2005) "Chrysophyte cysts from lake sediments reveal the submillennial winter/spring climate variability in the northwestern Mediterranean region throughout 
the Holocene", Climate Dynamics 24 (2005) 263-78: doi:10.1007/ soo382-004-0482-1.

Renberg I., Bindler R. and Brannvall M. L. (2001) “Using the historical atmospheric lead-deposition record as a chronological marker in sediment deposits in Europe" The Holocene 11 (2001) 511-16: doi:10.1191/095968301680223468.

Richards D. A. and Dorale J. A. (2003) "Uranium-series chronology and environmental applications of speleothems", Reviews in Mineralogy and Geochemistry $5^{2}$ (2003) 407-60: doi:10.2113/0520407.

Roberts N., Jones M. D., Benkaddour A. et al. (2008) "Stable isotope records of Late Quaternary climate and hydrology from Mediterranean lakes: the ISOMED synthesis", Quaternary Science Reviews 27 (2008) 2426-41: doi:10.1016/j.quascirev.2008.09.005.

Roberts N., Moreno A., Valero-Garcés B. L. et al. (2012) "Palaeolimnological evidence for an east-west climate see-saw in the Mediterranean since AD 9oo", Global and Planetary Change 84-85 (2012) 23-34: doi:10.1016/j.gloplacha.2011.11.002.

Sadori L., Giraudi C., Masi A., Magny M., Ortu E. and Zanchetta G. (2016) "Climate, environment and society in southern Italy during the last 2000 years. A review of the environmental, historical and archaeological evidence", Quaternary Science Reviews 136 (2016) 173-88: doi:10.1016/j.quascirev.2015.09.020.

Scholz D., Hoffmann D. L., Hellstrom J., Bronk Ramsey C. (2012) "A comparison of different methods for speleothem age modelling", Quaternary Geochronology 14 (2012) 94-104: doi:10.1016/j. quageo.2012.03.015.

Seager R., Graham N., Herweijer C., Gordon A. L., Kushnir Y., Cook E. (2007) "Blueprints for Medieval hydroclimate", Quaternary Science Reviews 26 (2007) 2322-36: doi:10.1016/j.quascirev.2007.04.020.

Sigl M., Winstrup M., McConnell J. R. et al. (2015) "Timing and climate forcing of volcanic eruptions for the past 2,500 years", Nature 523 (2015) 543-49: doi:10.1038/nature14565.

Smerdon J. E. (2012) "Climate models as a test bed for climate reconstruction methods: pseudoproxy experiments", WIREs Climate Change 3 (2012) 63-77.

Smith A. C., Wynn P. M., Barker P. A., Leng M. J., Noble S. R. and Tych W. (2016) "North Atlantic forcing of moisture delivery to Europe throughout the Holocene", Scientific Reports 6 (2016) 24745: doi:10.1038/srep24745.

Squatriti P. (1998) Water and Society in Early Medieval Italy: $A D$ 40o1000 (Cambridge 1998).

Telelis I. (2008) "Climatic fluactions in the eastern Mediterranean and the Middle East AD 300-1500 from Byzantine documentary and proxy physical paleoclimatic evidence-a comparison", JÖB 58 (2008) 167-208: doi:10.1553/joeb58s167.

Trigo R. M., Pozo-Vázquez D., Osborn T. J., Castro-Díez Y., GámizFortis S. and Esteban-Parra M. J. (2004) "North Atlantic oscillation influence on precipitation, river flow and water resources in the Iberian Peninsula", International Journal of Climatology 24 (2004) 925-44: doi:10.1002/joc.1048.

Walker M. J. C. (2005) Quaternary Dating Methods (Chichester 2005). Ward M. N., Lamb P. J., Portis D. H., El Hamly M. and Sebbari R. (1999) "Climate variability in northern Africa: understanding droughts in the Sahel and the Maghreb", in Beyond El Niño: Decadal and Interdecadal Climate Variability, ed. A Navarra (Berlin-Heidelberg 1999) 119-40: doi:10.1007/978-3-642-58369-8_6.

Wick L., Lemcke G. and Sturm M. (2003) "Evidence of Lateglacial and Holocene climatic change and human impact in eastern Anatolia", The Holocene 13 (2003) 665-75: doi:10.1191/o959683603hl653rp.

Witschel C. (2004) "Re-evaluating the Roman West in the 3rd c. A.D", JRA 17 (2004) 251-81: doi:10.1017/S1047759400008242.

Xoplaki E., González-Rouco J. F., Luterbacher J. and Wanner H. (2004) "Wet season Mediterranean precipitation variability: influence of large-scale dynamics and trends", Climate Dynamics 23 (2004) 63-78: doi:10.1007/soo382-004-0422-0.

Zanchetta G., Drysdale R. N., Hellstrom J. C., Fallick A. E., Isola I., Gagan M. K. and Pareschi M. T. (2007) "Enhanced rainfall in the western Mediterranean during deposition of sapropel S1: stalagmite evidence from Corchia cave (central Italy)", Quaternary Science Reviews 26 (2007) 279-86: doi:10.1016/j.quascirev.2006.12.003.

Zanchetta G., Regattieri E., Isola I., Drysdale R. N., Bini M., Baneschi I. and Hellstrom J. C. (2016) "The so-called '4.2 event' in the central Mediterranean and its climatic teleconnections", Alpine and Mediterranean Quaternary 29 (2016) 5-17.

Zanchetta G., Van Welden A., Baneschi I. et al. (2012) "Multiproxy record for the last 4500 years from Lake Shkodra (Albania/ Montenegro)", Journal of Quaternary Science 27 (2012) 780-89: doi:10.1002/jqs.2563.

Ziolkowski A. (2011) "The background to the third-century crisis of the Roman empire", in The Roman Empire in Context, edd.J. P. Arnason and K. A. Raaflaub (Oxford) 111-33: doi:10.1002/9781444390186. $\mathrm{ch}_{5}$.

Ziv B., Saaroni H. and Alpert P. (2004) "The factors governing the summer regime of the eastern Mediterranean", International Journal of Climatology 24 (2004) 1859-71: doi:10.1002/joc.1113.

Zolitschka B., Francus P., Ojala A. E. K. and Schimmelmann A. (2015) "Varves in lake sediments-a review", Quaternary Science Reviews 117 (2015) 1-41: doi:10.1016/j.quascirev.2015.03.019. 